\title{
Thermodynamic energy of anaerobic microbial redox reactions couples elemental biogeochemical cycles
}

\author{
Xin-Nan Wang ${ }^{1,2} \cdot$ Guo-Xin Sun ${ }^{1}$ Yong-Guan Zhu ${ }^{1,3}$
}

Received: 22 March 2017 / Accepted: 21 June 2017 / Published online: 13 July 2017

(C) Springer-Verlag GmbH Germany 2017

\begin{abstract}
Purpose The thermodynamic energy of redox reactions affects the distribution of microbial redox reactions and cyclic transformation of elements in various anaerobic ecosystems. The principle of thermodynamics is of dramatic significance in understanding the energetics of metabolic processes, the biogeochemical behavior of microorganisms, and mass and energy cycles. The purpose of this paper is to relate the distribution of the coupling reactions between $\mathrm{C}, \mathrm{N}, \mathrm{Fe}$, and $\mathrm{S}$, the most important elements involved in microbially mediated redox reactions, with their thermodynamic feasibility to provide theoretical foundation of their occurrence.

Results and discussion Anaerobic microorganisms catalyze diverse redox reactions in anoxic environments, driving elemental biogeochemical cycles on the earth. They capture energy from catalyzing these redox reactions in order to support life. The thermodynamic feasibility of these microbe-driven redox reactions is controlled by their energy yields which depend on environmental conditions. Anaerobic microorganisms can oxidize organic carbon with diverse inorganic compounds including nitrate/nitrite, ferric iron, and sulfate as electron acceptors in
\end{abstract}

Responsible editor: Kitae Baek

Yong-Guan Zhu

ygzhu@rcees.ac.cn

1 State Key Laboratory of Urban and Regional Ecology, Research Center for Eco-Environmental Sciences, Chinese Academy of Sciences, Shuangqing Road, No. 18, Haidian District, Beijing 100085, People's Republic of China

2 University of Chinese Academy of Sciences, Yuquan Road, No. 19A, Shijingshan District, Beijing 100049, People's Republic of China

3 Key Laboratory of Urban Environment and Health, Institute of Urban Environment, Chinese Academy of Sciences, Jimei Road, No. 1799, Jimei District, Xiamen 361021, People's Republic of China various anoxic environments which is referred to anaerobic respiration of organic matter; reversely, inorganic carbon can be reduced to synthesize cell material with ferrous iron and sulfide as an alternative electron donor by phototrophs under different sets of circumstances. Nitrate/nitrate can be microbically reduced by inorganic compounds such as ferrous iron and sulfide under some specific situations; the coupling of anaerobic anammox oxidation and reduction of nitrite (anammox), ferric iron (feammox), and sulfate (suramox) driven by anaerobes occurs in other particular systems.

Conclusions and perspectives Although there are increasing researches investigating the anaerobe-driven coupling of pairs of elements such as C-N, C-Fe, C-S, N-Fe, N-S, and Fe-S, much more intricate situations associating the coupling of multiple elements are still not comprehensively understood. A great many reactions which are thermodynamically feasible have not yet been identified in natural environments or laboratories. Further work focusing on the metabolic pathways from a genetic and enzymatic perspective and the factors controlling the feasibility of the reactions by using updated technical tools and methods is required.

Keywords Anaerobic microorganisms $\cdot$ Elemental biogeochemical cycles $\cdot$ Redox reactions $\cdot$ Thermodynamic energy

\section{Introduction}

Elemental biogeochemical cycles are largely driven by the electron transfer processes mediated by microorganisms, changing the chemistry of the earth's surface profoundly. Despite that the earth's surface is mostly oxic, anoxic environments are vast distributed, including deep marine, freshwater, soils, and sediments, providing habitats for diverse microorganisms. In these anoxic 
environments, anaerobic microorganisms perform complex redox reactions, driving the coupling of elements. The distribution of microbial redox reactions is controlled by the thermodynamic energy of redox reactions which depends on environmental conditions. For example, denitrification has been shown to be coupled to the oxidation of organic and inorganic compounds including carbon, ferrous iron, and sulfide in some particular situations (Canfield et al. 1993; Fossing et al. 1995; Laufer et al. 2016). Reversely, anaerobic oxidation of ammonium can be coupled to the reduction of nitrite, ferric iron, and sulfate under different sets of circumstances (Bender et al. 1989; Schrum et al. 2009; Ding et al. 2014). These redox reactions mediated by anaerobic microbes significantly promote the coupling of C-N, $\mathrm{Fe}-\mathrm{N}$, and S-N under anoxic environments. Iron undergoes cycles of reduction and oxidation as a terminal electron acceptor for organic carbon oxidation and an electron donor for inorganic carbon reduction under different conditions in anoxic environments making a dramatic contribution to the global biogeochemical coupling of C-Fe (Zhu et al. 2014). Thermodynamics provide a framework for predicting and verifying whether a specific reaction can occur spontaneously and to which extend it can reach the equilibrium. In this paper, we focus on the biogeochemical coupling between $\mathrm{C}, \mathrm{N}, \mathrm{Fe}$, and S (Fig. 1), the most important elements involved in microbially mediated redox reactions in anoxic environments. We comprehensively review the distribution of these redox reactions and the thermodynamic feasibility of the reactions in environments to provide theoretical evidence of their occurrence.

\section{Thermodynamic energy}

In order to support life, microbes harness energy released from the redox reactions (Jin and Bethke 2007). They transfer electrons from electron donors onto electron transport chains inside cell membrane, pumping out protons and fuelling adenosine triphosphate (ATP) synthesis to conserve energy. The electrons are then passed to terminal electron acceptors, and the whole redox reactions are completed (Jin and Bethke 2007). Burgin et al. (2011) proposed the concept of microbial energy economy which was a metaphor referring to the microbial metabolic pathways. Microorganisms capture raw materials from the surroundings to produce goods - biomolecules, such as proteins and nucleic acids, which are then used to supply service-energy production, growth, and biomolecule regeneration. Like a social economy, competitive relationships are involved between different microbial metabolic pathways because of their corresponding thermodynamic feasibility which is controlled by their energy yields (Burgin et al. 2011). Redox reactions proceed sequentially from the highest energy yields towards the lowest, following a thermodynamic ladder. The Gibbs free energy $(\Delta G)$ was developed to describe the amount of energy yields of reactions which involves the standard Gibbs free energy of formation $\left(\Delta_{f} G^{0}\right)$ and activities of the substrates and products:

$\Delta G=\Delta G^{0}+\mathrm{RT} \ln \mathrm{Q}$

where $\Delta G^{0}$ can be calculated from Eq. (2):

$\Delta G^{0}=\Sigma v_{p} \Delta_{f} G_{p}^{0}-\Sigma v_{s} \Delta_{f} G_{s}^{0}$

where $\Delta_{f} G_{p}^{0}$ and $\Delta_{f} G^{0}{ }_{s}$ are the standard Gibbs free energy of formation of the products and substrates, respectively $\left(\Delta_{f} G^{0}\right.$ values of the studied species in this paper are listed in Table 1), $v_{p}$ and $\nu_{s}$ stand for their stoichiometric coefficients. $R$ and $T$ (in Eq. (1)) represent the gas

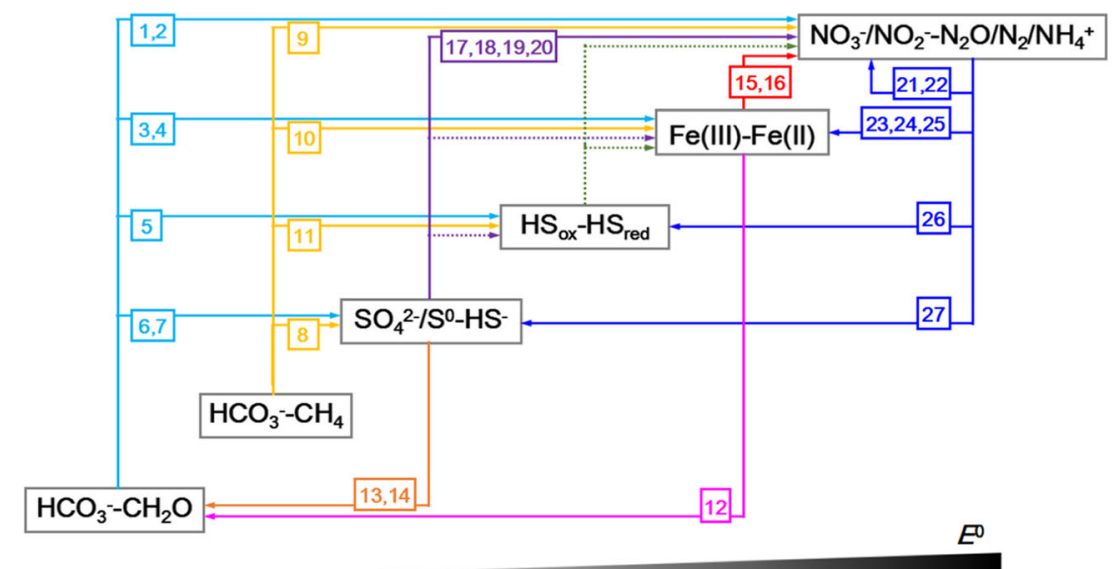

Fig. 1 Redox reactions between various compounds (C, N, Fe, and S) mediated by anaerobic microorganisms (dotted lines denote abiotic reactions). The redox couples are in an order of increasing standard reduction potential $E^{0}$ from left to right. Electrons transfer following the arrows. The number in each square stands for the formula in the following text. $\mathrm{HS}_{\mathrm{ox}}$ oxidized humic sunstances, $\mathrm{HS}_{\text {red }}$ reduced humic substances. $\mathrm{HS}_{\mathrm{ox}}-\mathrm{HS}_{\mathrm{red}}$ has a wide range of standard reduction potential. Here, we put it at an approximate position relative to $\mathrm{Fe}(\mathrm{III})$ $\mathrm{Fe}(\mathrm{II})$ and $\mathrm{SO}_{4}{ }^{2-} / \mathrm{S}^{0}-\mathrm{HS}^{-}$ 
Table 1 Gibbs free energy of formation $\left(\Delta_{f} G^{0}\right)$ of the studied constituents

\begin{tabular}{lc}
\hline Formula & $\Delta_{f} G^{0}(\mathrm{~kJ} / \mathrm{mol})$ \\
\hline $\mathrm{C}_{6} \mathrm{H}_{12} \mathrm{O}_{6}$ & $-915.90^{\mathrm{a}}$ \\
$\mathrm{HCO}_{3}{ }^{-}$ & $-586.77^{\mathrm{a}}$ \\
$\mathrm{CH}_{4}(\mathrm{aq})$ & $-34.46^{\mathrm{b}}$ \\
$\mathrm{H}_{2} \mathrm{O}$ & $-237.10^{\mathrm{a}}$ \\
$\mathrm{H}^{+}$ & $0.00^{\mathrm{a}}$ \\
$\mathrm{NO}_{3}{ }^{-}$ & $-108.74^{\mathrm{a}}$ \\
$\mathrm{NO}_{2}{ }^{-}$ & $-32.20^{\mathrm{a}}$ \\
$\mathrm{N}_{2}(\mathrm{aq})$ & $18.18^{\mathrm{b}}$ \\
$\mathrm{N}_{2} \mathrm{O}(\mathrm{aq})$ & $113.38^{\mathrm{b}}$ \\
$\mathrm{NH}_{4}{ }^{+}$ & $-79.31^{\mathrm{a}}$ \\
$\mathrm{Fe}(\mathrm{OH})_{3}$ & $-708.50^{\mathrm{c}}$ \\
$\alpha-\mathrm{FeOOH}$ & $-489.80^{\mathrm{d}}$ \\
$\mathrm{Fe}^{2+}$ & $-78.90^{\mathrm{a}}$ \\
$\mathrm{SO}_{4}{ }^{2-}$ & $-744.53^{\mathrm{a}}$ \\
$\mathrm{S}^{0}$ & $0.00^{\mathrm{a}}$ \\
$\mathrm{HS}^{-}$ & $12.08^{\mathrm{a}}$ \\
\hline
\end{tabular}

${ }^{\mathrm{a}}$ Lide (2012)

${ }^{\mathrm{b}}$ Amend and Shock (2001)

${ }^{c}$ Majzlan et al. (2004)

${ }^{\mathrm{d}}$ Majzlan et al. (2003) mol of substrate considering that at least one proton is translocated for the synthesis of ATP when one molecule substrate is oxidized (Hoehler et al. 1994). The minimum energy of a certain metabolic pathway can be determined via pure culture of microbes in the laboratory or estimated from knowledge of the respiratory chain (Jin and Bethke 2003, 2007). Fe(III) reducers need at least $56 \mathrm{~kJ}$ to support the oxidation of $1 \mathrm{~mol}$ acetate or $11 \mathrm{~kJ}$ to support the oxidation of $1 \mathrm{~mol} \mathrm{H}_{2}$ (Jin and Bethke 2009). Methanogens produce methane from acetate with $\mathrm{H}_{2} \mathrm{O}$ only when the energy yield exceeds the minimum energy of $11 \mathrm{~kJ} / \mathrm{mol}$ of acetate (Jin and Bethke 2007). The differing minimum energy required for diverse metabolism pathways influences their energetic efficiency with which substrates are utilized for growth and thus further the thermodynamic feasibility. This minimum energy needs to be considered especially when we judge the thermodynamic feasibility of one reaction with very low energy yield or compare the predominance of two reactions with similar energy generation.

\section{Anaerobic organic carbon oxidation}

\subsection{Anaerobic respiration of organic matter}

constant $(8.314 \mathrm{~J} / \mathrm{mol})$ and absolute temperature $(298.15 \mathrm{~K})$, respectively. $Q$ denotes the ion activity product according to Eq. (3):

$Q=\frac{\prod a_{p}{ }^{v_{p}}}{\prod a_{s}{ }^{v_{s}}}$

where $a_{p}$ and $a_{s}$ represent the activities of the products and substrates. We do not differentiate between concentrations and activities of ions because the values of activities in previous reports are often not available.

The value of $\Delta G$ reflects the thermodynamic feasibility of the reaction. An exergonic reaction which has a negative value of $\Delta G$ has the possibility to proceed spontaneously, while on the contrary, an endergonic reaction which has a positive value of $\Delta G$ is difficult to occur under the given conditions. Microbes can catalyze these redox reactions which means raising the reaction rates kinetically by lowering the activation energy to acquire energy for living although cannot change the thermodynamic equilibrium.

Generally, these reactions would not occur close to the limit of thermodynamic equilibrium, i.e., $\Delta G=0$ for the reason that minimum energy released from the reactions is required to support the growth of microorganisms (Bethke et al. 2011). However, some anaerobic microbes can grow by catalyzing these reactions ( $\Delta G$ values close to 0 ) (Conrad et al. 1986; Jackson and McInerney 2002). Different metabolic pathways have different values of minimum energy, with a rough range estimated to be $9 \sim 15 \mathrm{~kJ} /$
$\mathrm{C}_{6} \mathrm{H}_{12} \mathrm{O}_{6}+24 / 5 \mathrm{NO}_{3}{ }^{-} \rightarrow 6 \mathrm{HCO}_{3}{ }^{-}+12 / 5 \mathrm{~N}_{2}+6 / 5 \mathrm{H}^{+}+12 / 5 \mathrm{H}_{2} \mathrm{O}$

$\mathrm{C}_{6} \mathrm{H}_{12} \mathrm{O}_{6}+3 \mathrm{NO}_{3}{ }^{-}+3 \mathrm{H}_{2} \mathrm{O} \rightarrow 6 \mathrm{HCO}_{3}{ }^{-}+3 \mathrm{NH}_{4}{ }^{+}$

$\mathrm{C}_{6} \mathrm{H}_{12} \mathrm{O}_{6}+24 \mathrm{Fe}(\mathrm{OH})_{3}+42 \mathrm{H}^{+} \rightarrow 6 \mathrm{HCO}_{3}{ }^{-}+24 \mathrm{Fe}^{2+}+60 \mathrm{H}_{2} \mathrm{O}$

$\mathrm{C}_{6} \mathrm{H}_{12} \mathrm{O}_{6}+24 \alpha-\mathrm{FeOOH}+42 \mathrm{H}^{+} \rightarrow 6 \mathrm{HCO}_{3}^{-}+24 \mathrm{Fe}^{2+}+36 \mathrm{H}_{2} \mathrm{O}$

$\mathrm{C}_{6} \mathrm{H}_{12} \mathrm{O}_{6}+12 A Q D S+12 \mathrm{H}_{2} \mathrm{O} \rightarrow 6 \mathrm{HCO}_{3}{ }^{-}+12 \mathrm{AH}_{2} \mathrm{QDS}+6 \mathrm{H}^{+}$

$\mathrm{C}_{6} \mathrm{H}_{12} \mathrm{O}_{6}+3 \mathrm{SO}_{4}{ }^{2-} \rightarrow 6 \mathrm{HCO}_{3}{ }^{-}+3 \mathrm{HS}^{-}+3 \mathrm{H}^{+}$

$\mathrm{C}_{6} \mathrm{H}_{12} \mathrm{O}_{6}+12 \mathrm{~S}^{0}+12 \mathrm{H}_{2} \mathrm{O} \rightarrow 6 \mathrm{HCO}_{3}^{-}+12 \mathrm{HS}^{-}+18 \mathrm{H}^{+}$

Anaerobic respiration of organic matter has been a focus of researches for years because this distinct microbial process is ubiquitous in anoxic environments and of significance in decomposing biomass and regenerating nutrients for life (Canfield et al. 1993; Burgin et al. 2011). A vast variety of organic carbon can serve as electron donors with various chemicals as terminal electron acceptors for microorganisms in anoxic environments (Fig. 1). Typically, microbes oxidize organic carbon using electron acceptors in 
the order of $\mathrm{NO}_{3}{ }^{-}$(Considering that $\mathrm{NO}_{2}{ }^{-}$and $\mathrm{NO}_{3}{ }^{-}$ were not distinguished in some studies, we use $\mathrm{NO}_{3}{ }^{-}$to represent $\mathrm{NO}_{3}^{-}$and $\mathrm{NO}_{2}^{-}$in the formulas in the following discussion if not specially mentioned), $\mathrm{Fe}(\mathrm{III})$, and $\mathrm{SO}_{4}{ }^{2-}$, yielding progressively decreasing energy (Fig. 2) (Burgin et al. 2011). This energetic hierarchy of reduction processes is present in many natural environments (Froelich et al. 1979; Patrick and Jugsujinda 1992). For example, in a flooded soil with decreasing $\mathrm{O}_{2}$ diffused into the soil, the microorganisms respire switching from $\mathrm{O}_{2}$ to $\mathrm{NO}_{3}{ }^{-}$as an electron acceptor. Once $\mathrm{NO}_{3}{ }^{-}$is depleted, manganese or iron starts to be reduced following a thermodynamic ladder before sulfate reduction (Patrick and Jugsujinda 1992).

Different from the distinct interfaces between zones of $\mathrm{NO}_{3}{ }^{-}$reduction and $\mathrm{Fe}(\mathrm{III})$ reduction, there exist overlaps between zones of reduction of $\mathrm{Fe}(\mathrm{III})$ (oxyhydr)oxides and sulfur species (Postma and Jakobsen 1996). The thermodynamic order of $\mathrm{Fe}(\mathrm{III})$ reduction and sulfate reduction varies depending on the availability of substrates, concentration of products, and $\mathrm{pH}$. Microbial reduction of $\mathrm{Fe}(\mathrm{III})$ (oxyhydr)oxides strongly favors acidic $\mathrm{pH}$, while microbial sulfate reduction is more likely to occur at alkaline $\mathrm{pH}$. We compare the energy yields of the reduction of $\mathrm{Fe}(\mathrm{III})$ minerals (taking ferrihydrite and goethite as examples) and sulfur species $\left(\mathrm{S}^{0}\right.$ and $\left.\mathrm{SO}_{4}{ }^{2-}\right)$ (Fig. 2). According to our calculation, at

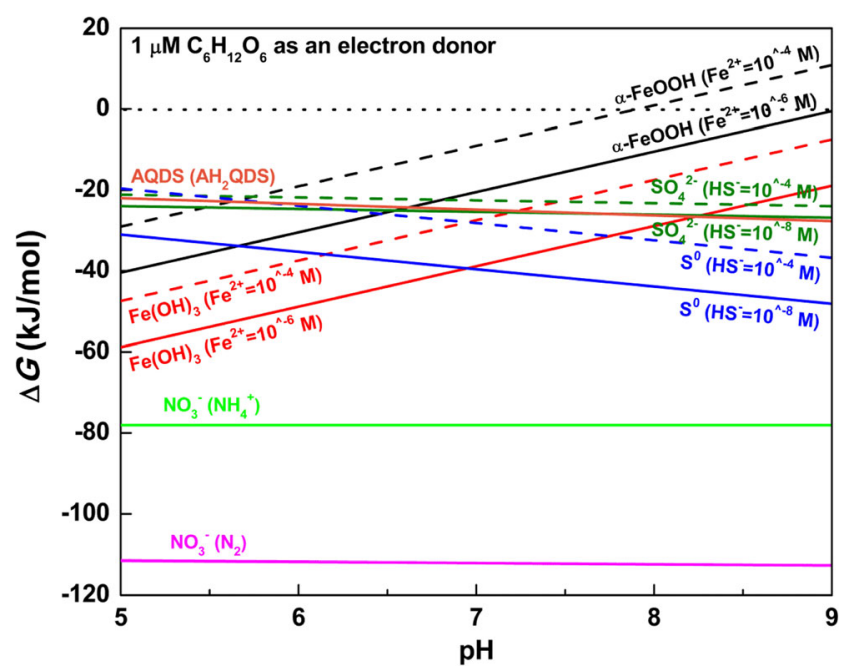

Fig. 2 Gibbs free energy $\Delta G$ of oxidation of glucose $(1 \mu \mathrm{M})$ with the reduction of $\mathrm{NO}_{3}^{-}(1 \mathrm{mM})$ to $\mathrm{N}_{2}\left(10^{-3.47} \mathrm{M}\right)$ or $\mathrm{NH}_{4}{ }^{+}(1 \mathrm{mM}), \mathrm{Fe}$ (III) containing minerals including ferrihydrite $\left(\mathrm{Fe}(\mathrm{OH})_{3}\right)$ and goethite $(\alpha-$ $\mathrm{FeOOH})$ to $\mathrm{Fe}^{2+}\left(10^{-6} \sim 10^{-4} \mathrm{M}\right)$, AQDS $(1 \mu \mathrm{M})$ to $\mathrm{AH}_{2} \mathrm{QDS}(1 \mu \mathrm{M})$, $\mathrm{SO}_{4}^{2-}(1 \mathrm{mM})$ to $\mathrm{HS}^{-}\left(10^{-8} \sim 10^{-4} \mathrm{M}\right)$, and $\mathrm{S}^{0}$ to $\mathrm{HS}^{-}\left(10^{-8} \sim 10^{-4} \mathrm{M}\right)$ alternatively in a $\mathrm{pH}$ range of $5 \sim 9$ (corresponding to formula $1 \sim 7$, values of $\Delta G$ are normalized as $\mathrm{kJ}$ per mole of $\mathrm{e}^{-}$transferred). The reactions are thermodynamically feasible below the dotted line at $\Delta G=0$ (minimum energy not taken into consideration) acidic $\mathrm{pH}(\mathrm{pH}=\sim 5)$, reduction of $\mathrm{Fe}(\mathrm{III})$ minerals is energetically more favored than sulfur and sulfate reduction. At neutral $\mathrm{pH}(\mathrm{pH}=\sim 7)$, both sulfur and sulfate reduction yield similar energy to ferrihydrite reduction but energetically predominate over the reduction of goethite (with higher crystallinity than ferrihydrite). At alkaline $\mathrm{pH}(\mathrm{pH}=\sim 9)$, sulfate and sulfur reduction are the favored processes compared with the reduction of ferrihydrite and goethite. Our calculation (data not shown) points out that among the common Fe(III) minerals, only ferrihydrite, the most unstable one, can be reduced at alkaline $\mathrm{pH}$ up to 9 which is consistent with previous researches (Wang et al. 2017). Actually, microbial reduction of $\mathrm{Fe}(\mathrm{III})$ minerals and sulfur species is often observed to occur simultaneously (Boesen and Postma 1988). Fe(III)- and sulfate-reducing microorganisms are found to live in a mutualistic relationship. The concentrations of reduction products, i.e., free $\mathrm{Fe}^{2+}$ and $\mathrm{HS}^{-}$, can be decreased because of the formation and precipitation of mackinawite $(\mathrm{FeS})$, driving forward both Fe(III) and sulfate reduction (Neal et al. 2001). Moreover, $\mathrm{S}^{0}$ produced from sulfate reduction can act as an electron shuttle to mediate microbial Fe(III) (oxyhydr)oxide reduction at alkaline environments (Flynn et al. 2014). Under this condition, $\mathrm{S}^{0}$ can be microbially reduced to $\mathrm{HS}^{-}$which then abiotically reduces Fe(III) (oxyhydr)oxides (Flynn et al. 2014).

Humic substance can also be electron acceptors of anaerobic respiration (Scott et al. 1998). Humic substances can accept electrons from anaerobic microorganisms and transfer them to solid Fe(III) minerals, facilitating microbial Fe(III) reduction (Newman and Kolter 2000; Huang et al. 2010). Not only dissolved but also particulate humic substances have shown an electron transfer capability (Roden et al. 2010). Quinones have been recognized as the dominant units of redox activities in humic substances (Scott et al. 1998). We calculated the energy yield of the reduction of AQDS, a commonly used quinone containing analogue of humic substances in laboratory, with glucose as an electron donor, and results showed that it is thermodynamically favorable in the range of pH 5 9 (Scott et al. 1998). Considering the complex composition and structures which cannot be totally represented by AQDS, humic substances would have a wide range of reduction potential, i.e., a wide range of standard Gibbs energy change of the half reaction of reduction (Klüpfel et al. 2014). It has been reported that the range of reduction potential over which humic substances can accept electrons overlap those of many other electron acceptors including $\mathrm{Fe}(\mathrm{III})$ (oxyhydr)oxides and sulfur species (Klüpfel et al. 2014). Therefore, the segregation between zones of reduction of humic substances and other electron acceptors is diffuse. 


\subsection{Anaerobic methane oxidation}

$\mathrm{CH}_{4}+\mathrm{SO}_{4}{ }^{2-} \rightarrow \mathrm{HCO}_{3}{ }^{-}+\mathrm{HS}^{-}+\mathrm{H}_{2} \mathrm{O}$

$\mathrm{CH}_{4}+8 / 5 \mathrm{NO}_{3}{ }^{-}+3 / 5 \mathrm{H}^{+} \rightarrow \mathrm{HCO}_{3}{ }^{-}+4 / 5 \mathrm{~N}_{2}+9 / 5 \mathrm{H}_{2} \mathrm{O}$

$\mathrm{CH}_{4}+8 \mathrm{Fe}(\mathrm{OH})_{3}+15 \mathrm{H}^{+} \rightarrow \mathrm{HCO}_{3}{ }^{-}+8 \mathrm{Fe}^{2+}+21 \mathrm{H}_{2} \mathrm{O}(10)$

$\mathrm{CH}_{4}+4 \mathrm{AQDS}+3 \mathrm{H}_{2} \mathrm{O} \rightarrow \mathrm{HCO}_{3}{ }^{-}+\mathrm{H}^{+}+4 \mathrm{AH}_{2} \mathrm{QDS}$

Anaerobic oxidation of methane (AOM) is a unique microbial process performed mainly by methane-oxidizing archaea. AOM provides a major sink in methane geochemistry, consuming approximately $90 \%$ of global methane production (Reeburgh 2007). Up to date, a variety of chemical compounds including sulfate (Moran et al. 2008), nitrate (Haroon et al. 2013), metal (Fe(III) and $\mathrm{Mn}(\mathrm{IV})$ ) oxides (Beal et al. 2009), and AQDS (Scheller et al. 2016) have been reported to be electron acceptors of AOM. Sulfate-driven $\mathrm{AOM}$, among the pathways with various electron acceptors, was the most investigated one and has been reported to be the dominant pathway for methane removal in ocean sediments (Canfield et al. 1993). Multiple anaerobic methanotrophic archaeal lineages were reported to form syntrophic consortia with sulfate-reducing bacteria to drive AOM in marine habitats though the electron transport mechanism involved is still unclear (McGlynn et al. 2015). But, it has also been reported that anaerobic methanotrophs might couple methane oxidation and sulfate reduction independently (Milucka et al. 2012). At environmental conditions, the coupling of methane oxidation and sulfate reduction is exoergic but yields very small amount energy of only $-5.0 \sim-2.5 \mathrm{~kJ} / \mathrm{mol}$ of $\mathrm{e}^{-}$transferred, leading to a slow growth of 2-month generation times of the AOM consortia (Wegener et al. 2015). Nitratedependent methane oxidation is more thermodynamically favorable than sulfate-dependent methane oxidation, yielding $-95.3 \mathrm{~kJ} / \mathrm{mol}$ of $\mathrm{e}^{-}$transferred at $\mathrm{pH} 7$ at environmental conditions (Zehnder and Brock 1980). However, the process of denitrifying AOM has only been observed in laboratory but not in nature (Raghoebarsing et al. 2006). It was speculated that this process only occurred within millimeters in the oxic/ anoxic interface of sediments where methane and nitrate often coexisted, making it difficult to detect (Raghoebarsing et al. 2006). It was shown that methane oxidation and nitrate reduction could be coupled by methanotrophic archaea in concert with denitrifying partner bacteria or methanotrophic archaea alone (Ettwig et al. 2010). Metal (oxyhydr)oxides (birnessite and ferrihydrite) can also be electron acceptors of AOM in marine methane-seep sediments. Birnessite- and ferrihydritedependent methane oxidation was reported to have energy yields $\left(-33.8\right.$ and $-69.5 \mathrm{~kJ} / \mathrm{mol}$ of $\mathrm{e}^{-}$transferred at in situ conditions) higher than sulfate-dependent methane oxidation, but much slower rates (14 and $6 \mu \mathrm{mol} / \mathrm{year} / \mathrm{cm}^{3}{ }_{\text {sed }}$ ) than sulfate methane oxidation $\left(52 \mu \mathrm{mol} / \mathrm{year} / \mathrm{cm}^{3}{ }_{\text {sed }}\right.$ ) (Beal et al. 2009). The rates of Mn(IV)- and Fe(III)-driven methane oxidation may be limited by the solid phase manganese and iron (oxyhydr)oxides which are relatively difficult to utilize for microorganisms. It has been recently found that microorganisms could use humic acids and quinone-containing humic acids AQDS (2,6-AQDS), 1,5-AQDS, and 2,7-AQDS to oxidize methane directly without syntrophic interaction in a methane seep sediment (Scheller et al. 2016). The rate of AQDS-driven AOM was comparable with sulfate-driven AOM in the incubation. It indicated that AOM would also have the ability to reduce solid metal (oxyhydr)oxides with humic acids or other soluble compounds as electron shuttles which supported the finding of AOM-coupled Fe(III) reduction (Scheller et al. 2016). Direct evidence of Fe(III)-driven AOM in cold seep sediments in the northern Okinawa was provided by Peng et al. (2017) from the geological record. They illustrated a model that $\mathrm{Fe}(\mathrm{III})$-driven AOM occurred in the zone where methane and reducible Fe(III) (oxyhydr)oxides were both abundant, while sulfate was completely consumed because of sulfate-driven AOM above this zone. Dissolved $\mathrm{Fe}^{2+}$ generated from Fe-driven AOM would migrate with upwelling seep fluids to the zone of sulfate-driven AOM and react with sulfide to form the precipitation of pyrites or mackinawite. Therefore, sulfate-driven $\mathrm{AOM}$ and $\mathrm{Fe}(\mathrm{III})$-driven AOM may contribute together to prevent methane emission from seeps (Peng et al. 2017).

\section{Anaerobic $\mathrm{HCO}_{3}{ }^{-}$reduction by inorganic compounds}

\subsection{Anaerobic $\mathrm{HCO}_{3}{ }^{-}$reduction by $\mathrm{Fe}(\mathrm{II})$}

$$
\begin{gathered}
\mathrm{HCO}_{3}{ }^{-}+4 \mathrm{Fe}^{2+}+10 \mathrm{H}_{2} \mathrm{O} \rightarrow\left(\mathrm{CH}_{2} \mathrm{O}\right) \\
+4 \mathrm{Fe}(\mathrm{OH})_{3}+7 \mathrm{H}^{+}
\end{gathered}
$$

(where $\left(\mathrm{CH}_{2} \mathrm{O}\right)$ represents simplified composition of cell material)

Photoferrotrophs can use $\mathrm{Fe}(\mathrm{II})$ to reduce $\mathrm{HCO}_{3}{ }^{-}$for assimilation into cell material in $\mathrm{HCO}_{3}{ }^{-}$- and $\mathrm{Fe}^{2+}$-rich environments. Phototrophs utilize solar electromagnetic radiation for energy generation; therefore, they only live in habitats exposed to light. Photoautotrophic Fe(II)-oxidation has been 
used to explain the appearance of $\mathrm{Fe}(\mathrm{III})$ (oxyhydr)oxides in ancient banded iron formations (BIFs) (Widdel et al. 1993; Miot et al. 2009) and the primary production of organic matter (Canfield et al. 2006) before the occurrence of oxygenic phototrophs (including plants, algae, and cyanobacteria who are responsible for most of the primary production on the present earth) on the early earth (ca. 3.8 2.2 Ga) (Kasting 1993). Photoautotrophic Fe(II) oxidation happened when downward diffusion of $\mathrm{CO}_{2}$ from shallow, $\mathrm{CO}_{2}$-rich layer caused by the activity of microbial mats intercepted Fe(II) upwelling from deep waters (Tice and Lowe 2004). Anoxygenic phototrophs were evidenced to thrive within a ferruginous chemocline in modern environments such as Lake Matano (Crowe et al. 2008). A previous research indicated that photoferrotrophs produce poorly crystalline ferric (oxyhydr)oxides (ferrihydrite), which then age into crystalline minerals goethite or lepidocrocite (Kappler and Newman 2004). The reaction tends to occur at high $\mathrm{pH}$ as the reaction is proton-producing. But, it has also been reported that photoferrotrophs could oxidize Fe(II) only in dissolved phase, thus setting an upper limit to $\mathrm{pH}$ (Martin 1990). The $\mathrm{pH}$ dependence of the feasibility of photoautotrophic Fe(II) oxidation, in turn, may explain why photoferrotrophs usually grow at such a narrow $\mathrm{pH}$ range (strain $\mathrm{L} 7$ grows at $\mathrm{pH} 6.0$ to 7.5, with an optimum $\mathrm{pH}$ at 7.0; SW2 grows at $\mathrm{pH} 5.5$ to 7.0 , with an optimum pH at 6.5) (Ehrenreich and Widdel 1994).

\subsection{Anaerobic $\mathrm{HCO}_{3}{ }^{-}$reduction by $\mathrm{HS}^{-}$}

$$
\mathrm{HCO}_{3}{ }^{-}+2 \mathrm{HS}^{-}+3 \mathrm{H}^{+} \rightarrow\left(\mathrm{CH}_{2} \mathrm{O}\right)+2 \mathrm{~S}^{0}+2 \mathrm{H}_{2} \mathrm{O}
$$

$$
\mathrm{HCO}_{3}{ }^{-}+1 / 2 \mathrm{HS}^{-}+1 / 2 \mathrm{H}^{+} \rightarrow\left(\mathrm{CH}_{2} \mathrm{O}\right)+1 / 2 \mathrm{SO}_{4}{ }^{2-}
$$

Bacteria can also play the roles of primary producers to use sulfide as an electron donor in anoxygenic photosynthesis in sulfide- and bicarbonate-rich freshwater, marine, and particularly hot springs where anoxygenic phototrophic oxidation of sulfide is the dominant way of primary production (Blankenship et al. 1995). In this process, sulfide is oxidized to elemental sulfur or further oxidized to sulfate. Photoautotrophic sulfur oxidation is also a candidate contributor to early earth primary production (Canfield and Raiswell 1999). Sulfide derived from subaerial volcanic and terrestrial hydrothermal systems would enter the early earth surface and get involved in primary production (sulfide flux from the deep-ocean hydrothermal systems would have not made an important contribution to early earth primary production because it would have probably precipitated with dissolved $\mathrm{Fe}^{2+}$ in the oceans which is mentioned above).

\section{Anaerobic $\mathrm{NO}_{3}{ }^{-} / \mathrm{NO}_{2}{ }^{-}$reduction by inorganic compounds}

\subsection{Anaerobic $\mathrm{NO}_{3}{ }^{-}$reduction by $\mathrm{Fe}(\mathrm{II})$}

$$
\begin{aligned}
& \mathrm{NO}_{3}{ }^{-}+5 \mathrm{Fe}^{2+}+12 \mathrm{H}_{2} \mathrm{O} \rightarrow 5 \mathrm{Fe}(\mathrm{OH})_{3}+1 / 2 \mathrm{~N}_{2}+9 \mathrm{H}^{+} \\
& \mathrm{NO}_{3}{ }^{-}+4 \mathrm{Fe}^{2+}+19 / 2 \mathrm{H}_{2} \mathrm{O} \rightarrow 4 \mathrm{Fe}(\mathrm{OH})_{3}+1 / 2 \mathrm{~N}_{2} \mathrm{O}+7 \mathrm{H}^{+}
\end{aligned}
$$

Fe(II) commonly accumulated as an end product of microbial $\mathrm{Fe}$ (III) reduction in natural environments has been observed to be re-oxidized in many pure cultures and sediment enrichments (Benz et al. 1998; Blöthe and Roden 2009; Laufer et al. 2016), accompanied by $\mathrm{NO}_{3}{ }^{-} / \mathrm{NO}_{2}{ }^{-}$reduction to $\mathrm{N}_{2} \cdot \mathrm{NO}_{2}{ }^{-}$can chemically oxidize $\mathrm{Fe}(\mathrm{II})$ without catalysis, but the abiotic reaction of $\mathrm{NO}_{3}{ }^{-}$with $\mathrm{Fe}$ (II) only occurs in the presence of microorganisms or surface catalysis such as lepidocrocite and green rust or trace metals like $\mathrm{Cu}^{2+}$ (Sørensen and Thorling 1991; Hansen et al. 1996; Ottley et al. 1997; Picardal 2012). In the process of Fe(II)-dependent $\mathrm{NO}_{3}{ }^{-}$reduction, diverse species of $\mathrm{Fe}$ (II) including soluble $\mathrm{Fe}(\mathrm{II})$ or $\mathrm{Fe}$ (II) containing minerals like siderite and magnetite can act as electron donors (Benz et al. 1998; Chaudhuri et al. 2001). In addition to $\mathrm{N}_{2}, \mathrm{~N}_{2} \mathrm{O}$ was reported to be one of the products of $\mathrm{Fe}(\mathrm{II})$-dependent $\mathrm{NO}_{3}{ }^{-}$reduction (Muehe et al. 2009). Based on our thermodynamic calculation, reduction of $\mathrm{NO}_{3}{ }^{-}$to $\mathrm{N}_{2}$ or $\mathrm{N}_{2} \mathrm{O}$ coupled to $\mathrm{Fe}$ (II) oxidation is exoergic generating $-75.5 \sim-61.7$ or $-61.3 \sim-47.1 \mathrm{~kJ} / \mathrm{mol}$ of $\mathrm{e}^{-}$transferred at $\mathrm{pH}$ 7.0. It is controversial whether the couple of $\mathrm{Fe}(\mathrm{II})$ oxidization and $\mathrm{NO}_{3}{ }^{-}$reduction is directly enzymatically catalyzed in the microcosm incubations (Canfield and Raiswell 1999; Straub et al. 1996). One of the intermediates of microbial denitrification, $\mathrm{NO}_{2}^{-}$, can chemically oxidize $\mathrm{Fe}(\mathrm{II})$; therefore, the observed coupling of $\mathrm{NO}_{3}^{-}$reduction and $\mathrm{Fe}$ (II) oxidization in the microcosm incubations might just be a by-product of denitrification. Most known Fe(II)-oxidizing $\mathrm{NO}_{3}{ }^{-}$-reducing microbes live mixotrophically and therefore require an organic carbon source for the oxidation of $\mathrm{Fe}$ (II) over a long period (Hansen et al. 1996; Straub et al. 2004). Recently, researchers confirmed that $\mathrm{NO}_{3}{ }^{-}$reduction coupled to $\mathrm{Fe}$ (II) oxidation can be catalyzed by microorganisms (Robertson et al. 2016). They determined stoichiometries of $\mathrm{Fe}(\mathrm{II})$ oxidation and nitrate reduction in microcosm incubations and the incorporation of ${ }^{14} \mathrm{C}$ from labeled bicarbonate and proved the existence of autotrophic $\mathrm{Fe}(\mathrm{II})$-oxidizing $\mathrm{NO}_{3}{ }^{-}$-reducing bacteria in marine sediments. Nevertheless, genetic and enzymatic evidence for the presence of enzymatically catalyzed $\mathrm{Fe}$ (II)-oxidizing $\mathrm{NO}_{3}{ }^{-}$-reducing pathway is still lacking (Chakraborty et al. 2011). The actual existence 
of autotrophic nitrate-dependent Fe(II) oxidation in the natural environments also needs to be investigated.

\subsection{Anaerobic $\mathrm{NO}_{3}{ }^{-} / \mathrm{NO}_{2}{ }^{-}$reduction by sulfide}

$$
\begin{aligned}
& \mathrm{NO}_{3}{ }^{-}+5 / 2 \mathrm{HS}^{-}+7 / 2 \mathrm{H}^{+} \rightarrow 5 / 2 \mathrm{~S}^{0}+1 / 2 \mathrm{~N}_{2}+3 \mathrm{H}_{2} \mathrm{O} \\
& \mathrm{NO}_{3}{ }^{-}+5 / 8 \mathrm{HS}^{-}+3 / 8 \mathrm{H}^{+} \rightarrow 5 / 8 \mathrm{SO}_{4}{ }^{2-}+1 / 2 \mathrm{~N}_{2}+1 / 2 \mathrm{H}_{2} \mathrm{O} \\
& \mathrm{NO}_{3}{ }^{-}+4 \mathrm{HS}^{-}+6 \mathrm{H}^{+} \rightarrow 4 \mathrm{~S}^{0}+\mathrm{NH}_{4}{ }^{+}+3 \mathrm{H}_{2} \mathrm{O} \\
& \mathrm{NO}_{3}{ }^{-}+\mathrm{HS}^{-}+\mathrm{H}^{+}+\mathrm{H}_{2} \mathrm{O} \rightarrow \mathrm{NH}_{4}{ }^{+}+\mathrm{SO}_{4}{ }^{2-}
\end{aligned}
$$

Nitrate/nitrite-reducing bacteria can also use sulfide as an electron donor besides organic carbon or $\mathrm{Fe}(\mathrm{II})$ under anoxic environments (Ottley et al. 1997). In these ecosystems, nitrate/nitrite can be microbially reduced to nitrogen or ammonia when sulfide is oxidized to elemental sulfur or further sulfate (Burgin and Hamilton 2008; Payne et al. 2009). Microbial nitrate/nitrite reduction coupled to sulfide oxidation was first documented in marine ecosystems where sulfide is rich (Fossing et al. 1995). It has been increasingly revealed that the coupling of nitrate/nitrite reduction and sulfide oxidation plays an important biogeochemical role in freshwater systems with low sulfide as well (Burgin and Hamilton 2008; Payne et al. 2009; Yang et al. 2012a). Based on our thermodynamic calculation, nitrate reduction to nitrogen coupled to sulfide oxidation to sulfate is thermodynamically feasible yielding $-88.4 \sim-84.7 \mathrm{~kJ} / \mathrm{mol}$ of $\mathrm{e}^{-}$transferred. Because the primary source of sulfide is usually microbial sulfate reduction, sulfide-driven nitrate/nitrite reduction tends to contribute significantly to nitrate/nitrite removal mainly in suboxic zones with sufficient sulfate inputs and high carbon inputs which supports microbial sulfate reduction (Ottley et al. 1997). It was reported that quinones can facilitate simultaneous removal of sulfide and nitrate/nitrite by abiotically oxidizing sulfide and transferring electrons to denitrifying microorganisms (Aranda-Tamaura et al. 2007). Thus, quinones may also play the role of electron shuttles in mediating the couple of sulfide oxidation and nitrate/nitrite reduction. Sulfide oxidation was reported to attribute to $30 \%$ of the overall nitrate removal in a stratified lake in Spain and 10 40\% in freshwater ecosystems (15 40\% in lakes, $15 \sim 25 \%$ in streams, and $10 \sim 15 \%$ in wetlands) in Michigan (Burgin and Hamilton 2008).

\section{Anaerobic anammox oxidation by inorganic compounds}

Ammonia was naturally produced by microorganisms in water and soils as an end product of plant and animal waste decomposition. A large amount of ammonia enters the environment, on the other hand, through nitrogenbased fertilizers applied in agricultural fields for purpose of high productivity. The excess ammonia has caused various environmental problems, such as water eutrophication and habitat degradation (Bond and Lovley 2002; Balci and Dincel 2002).

\subsection{Anammox}

Ammonium in the soils was reported to be anaerobically oxidized coupled with nitrate and nitrite reduction (anammox) as a mechanism of $\mathrm{N}$ removal in natural ecosystems. At first, both nitrite and nitrate were assumed to function as electron acceptors (Bender et al. 1989; Zhu et al. 2008; Shen et al. 2014):

$\mathrm{NH}_{4}{ }^{+}+\mathrm{NO}_{2}^{-} \rightarrow \mathrm{N}_{2}+2 \mathrm{H}_{2} \mathrm{O}$

$\mathrm{NH}_{4}{ }^{+}+3 / 5 \mathrm{NO}_{3}{ }^{-} \rightarrow 4 / 5 \mathrm{~N}_{2}+9 / 5 \mathrm{H}_{2} \mathrm{O}+2 / 5 \mathrm{H}^{+}$

But, anammox bacteria were found to prefer nitrite rather than nitrate (Zhu et al. 2008). Anammox is thermodynamically favorable at typical environments, such as marine sediments, freshwater sediments, and paddy soils, where the concentrations of both $\mathrm{NH}_{4}{ }^{+}$and $\mathrm{NO}_{3}{ }^{-} / \mathrm{NO}_{2}{ }^{-}$ are much higher than the minimum requirement for the anammox reaction (Fig. 3) (Hamersley et al. 2009; Rich et al. 2008; Zhu et al. 2015). Anammox in natural environments was first observed in sediments from the BalticNorth Sea transition (Dalsgaard and Thamdrup 2002). It was surprising that anammox contributed to $24 \sim 67 \%$ of the total $\mathrm{N}_{2}$ production in continental shelf sediments, whereas the remainder was related to denitrification (Dalsgaard and Thamdrup 2002). Besides the common marine ecosystem, anammox also occurred in fresh water and terrestrial ecosystems (Zhu et al. 2015), especially in the suboxic water layer in a lacustrine system, like Lake Tanganyika, where anammox rates was up to $10 \mathrm{nM} \mathrm{N} \mathrm{N}_{2}$ / $\mathrm{h}$, comparable to the marine water column (Schubert et al. 2006). The anammox reaction was estimated to contribute to $19 \sim 35$ and $19 \%$ of total $\mathrm{N}_{2}$ production in anoxic water column of Golfo Dulce, Costa Rica and in ice floe from the Greenland respectively (Dalsgaard et al. 2003; Rysgaard and Glud 2004). Bacteria responsible for anammox was firstly identified in the Black Sea and identified as 


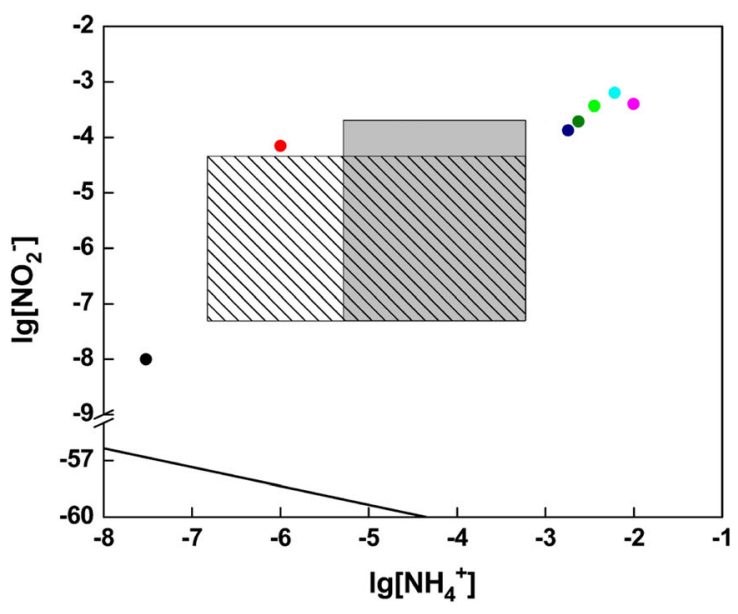

anoxic water column of Lake Rassnitzer in Germany

$\Delta I \nabla$ continental shelf sediments of the Irish Sea; continental slope sediments of the Celtic Sea; deep-sea sediments off the Washington margin; sediments of Chesapeake Bay; sediments of Choptank River; sediments of Patuxent River; Leonard's hot spring, California; Ray'shot spring, California; Patua-Hazenhot spring, Nevada; Lee's hot spring, Nevada; sediments of Disko Bay, West of Greenland; permanently cold sediments of young sound, Greenland; sediments of skagerrk; sediments of Gullmarsfjorde

- sediments at Cape Fear River Estuary, North Carolina

- oxygen minimum zone of the Arabian Sea

- sediments of rivers (Bulukeyi River, Songhua River, Yellow River, Tieshanping River, Yongding River, Tarim River, Turpan River, Pearl River, Tieshanping Ditch, North Canal) in China

- sediments of lakes (Chaohu Lake, Bosten Lake, Tianchi Lake, Wuliangsuhai Lake, Yuanmingyuan Lake, Baiyangdian Lake, Poyang Lake, Dongting Lake) in China

- sediments of swamps (Jiamusi swamps, Shimen swamps, Panjin swamps, Changbaishan Peatland, Duolun Peatland) in China

- sediments of paddy soils (Yinchuan Paddyfield, Yanbian Paddyfield, Meihekou Paddyfield, Changshu Paddyfield, Hunan Paddyfield) in China

- sediments of reservoirs (Antu Reservior, Shangqiu Reservior) in China

Fig. 3 The relationship between $\mathrm{NO}_{2}{ }^{-}$and $\mathrm{NH}_{4}{ }^{+}$when anammox reaches the thermodynamic equilibrium indicated by the solid line. Above the line, the reaction is thermodynamically feasible (minimum energy not taken into consideration). Shaded areas and dots in different colors reflect field data with the occurrence of anammox taken from previous literatures (Zhu et al. 2015; Schmid et al. 2007; Dale et al. 2009; Jaeschke et al. 2007; Rich et al. 2008; Hamersley et al. 2009; Jaeschke et al. 2009a, b; Engstrom et al. 2009)

Planctomycetales, similar to those isolated in bioreactors through fluorescently labeled RNA probes and the detection of ladderane membrane lipids unique to the bacterial anammoxosome (Kuypers et al. 2003).

\subsection{Feammox}

$\mathrm{Fe}(\mathrm{III})$ can also act as an electron acceptor of anaerobic ammonia oxidation which process was named as feammox. In recent years, there have been increasing researches on feammox (Clément et al. 2005; Shrestha et al. 2009; Yang et al. 2012b). Ammonia can be microbially oxidized to $\mathrm{N}_{2}$, $\mathrm{NO}_{2}{ }^{-}$, or $\mathrm{NO}_{3}{ }^{-}$coupled with the reduction of $\mathrm{Fe}(\mathrm{III})$ minerals ( $\mathrm{Fe}(\mathrm{III})$ is written in the form of ferrihydrite $\left(\mathrm{Fe}(\mathrm{OH})_{3}\right)$ ) (Yang et al. 2012b):

$$
\begin{aligned}
& \text { Feammox }-\mathrm{N}_{2}: \mathrm{NH}_{4}^{+} \\
& +3 \mathrm{Fe}(\mathrm{OH})_{3}+5 \mathrm{H}^{+} \rightarrow 3 \mathrm{Fe}^{2+}+9 \mathrm{H}_{2} \mathrm{O}+1 / 2 \mathrm{~N}_{2}
\end{aligned}
$$

$$
\begin{aligned}
& \text { Feammox }-\mathrm{NO}_{2}^{-}: \mathrm{NH}_{4}^{+} \\
& +6 \mathrm{Fe}(\mathrm{OH})_{3}+10 \mathrm{H}^{+} \rightarrow 6 \mathrm{Fe}^{2+}+16 \mathrm{H}_{2} \mathrm{O}+\mathrm{NO}_{2}{ }^{-}
\end{aligned}
$$

$$
\begin{aligned}
& \text { Feammox }-\mathrm{NO}_{3}{ }^{-}: \mathrm{NH}_{4}{ }^{+} \\
& +8 \mathrm{Fe}(\mathrm{OH})_{3}+14 \mathrm{H}^{+} \rightarrow 8 \mathrm{Fe}^{2+}+21 \mathrm{H}_{2} \mathrm{O}+\mathrm{NO}_{3}{ }^{-}
\end{aligned}
$$

Direct evidence of feammox- $\mathrm{NO}_{2}{ }^{-}$process was firstly provided in soils (from a forested riparian wetland in New Jersey, pH 4.8) amended with urea (Clément et al. 2005). It was confirmed that ammonia could be oxidized to nitrogen coupled to iron reduction in the absence of initial $\mathrm{NO}_{3}{ }^{-}$/ $\mathrm{NO}_{2}^{-}$(Shrestha et al. 2009). Ammonia was observed to be oxidized to nitrogen in upland soils, paddy soils, intertidal wetland (Yang et al. 2012b; Ding et al. 2014; Li et al. 2015), nitrite in wetland soils (Shrestha et al. 2009), and nitrate in anaerobic sludge via feammox (Sawayama 2006; Park et al. 2009). The bacteria responsible for feammox has not been isolated so far, but researchers have identified an uncultured Acidimicrobiaceae bacterium A6 as potential because it was one of the dominate microbes in a feammox system (Huang et al. 2014).

Feammox are much more favored at acidic conditions than at alkaline conditions (Fig. 4). It was estimated that feammox can only occur under the circumstance of $\mathrm{pH}<6.5$ (Yang et al. 2012b). High accumulation of free $\mathrm{Fe}^{2+}$ would lower the reaction free energy yield thus impeding the forward proceeding of the reactions as well. According to our calculation, ferrihydrite-driven ammonia $\left(\mathrm{NH}_{4}{ }^{+}=10^{-3} \mathrm{M}\right)$ oxidation to $\mathrm{N}_{2}$ and $\mathrm{NO}_{3}{ }^{-}$can proceed when $\mathrm{Fe}^{2+}$ is under $\sim 10^{-2.9}$ and $10^{-12.6} \mathrm{M}$ at $\mathrm{pH} 7$, the latter of which is much lower than the common cases, indicating that feammox- $\mathrm{NO}_{3}{ }^{-}$is thermodynamically unfavorable at neutral $\mathrm{pH}$ (Fig. 4). Huang et al. (2014) applied different iron sources including 6-line ferrihydrite, goethite, ferric chloride, and ferric citrate to investigate the possibilities of them to serve as electron acceptors of ammonia oxidation. They confirmed that feammox only occurred in samples amended with ferrihydrite and goethite. The possible explanation was that the concentration of produced ferrous ion was low due to its adsorption to ferrihydrite and goethite, which might create the condition for the feasibility of feammox reaction, or feammox bacteria might only have the ability to reduce iron (oxyhydr)oxides, as is the case for some iron reducers (Huang et al. 2014). Investigation by Park et al. (2009), however, showed that ferric citrate drove feammox process in anaerobic sludge from a piggery wastewater. Chelators such as citrate may raise the $\mathrm{Fe}$ (III)/Fe(II) reduction potential, therefore driving forward the reaction of feammox. Many organic molecules such as dissolved humic substances can chelate and solubilize Fe(III). Therefore, 


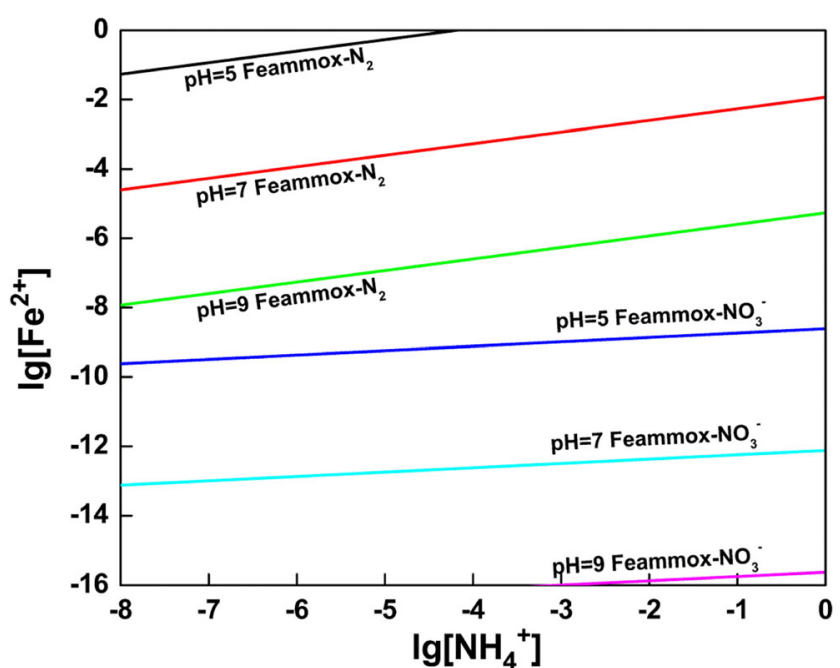

Fig. 4 The relationships between $\mathrm{Fe}^{2+}$ and $\mathrm{NH}^{4+}$ when feammox- $\mathrm{N}_{2}$ and $\mathrm{NO}_{3}{ }^{-}$reach the thermodynamic equilibrium at different $\mathrm{pHs}(\mathrm{pH}=5,7,9)$ indicated by the corresponding solid lines. Below the corresponding lines, the reactions are thermodynamically feasible (minimum energy not taken into consideration). Field or laboratory data with the occurrence of feammox are not available

chelated $\mathrm{Fe}$ (III) may have the potential to play a role in feammox in the nature. But, evidence remains to be provided whether and to which extent chelated Fe(III) in the nature can drive anaerobic ammonia oxidation.

Though feammox is less thermodynamically feasible compared with anammox (see Fig. 7), feammox cannot be overlooked when considering nitrogen loss from soils. Feammox was estimated to occur at the rate of $0.17 \sim 0.59 \mathrm{mg} \mathrm{N} / \mathrm{kg} /$ day in paddy soils in China (Ding et al. 2014) and approximately $0.32 \mathrm{mg} \mathrm{N} / \mathrm{kg}$ /day in tropical forest soils (Yang et al. 2012b). Feammox drove a nitrogen loss of $7.8 \sim 61 \mathrm{~kg} \mathrm{~N} / \mathrm{ha} /$ year in $(0 \sim 10 \mathrm{~cm}$ depth) paddy soils in China which accounted for about $3.9 \sim 31 \%$ of the $\mathrm{N}$ fertilizer applied to paddy soils comparable to $23 \%$ reported for anammox in paddy soils (Ding et al. 2014).

$\mathrm{NH}_{4}{ }^{+}+\mathrm{HS}_{\mathrm{ox}} \rightarrow \mathrm{HS}_{\mathrm{red}}+\mathrm{N}_{2} / \mathrm{NO}_{2}^{-} / \mathrm{NO}_{3}^{-}$

It was reported that AQDS can function as an electron shuttle to facilitate feammox, which indicates that bacterial AQDS reduction is also coupled to ammonia oxidation (Zhou et al. 2016). Therefore, humic substances, which are rich in quinone moieties like AQDS, are likely to be potential electron acceptors of bacterial ammonia oxidation despite no evidence yet. We calculated the thermodynamic feasibility of the reduction of common quinones (Table 2) coupled to ammonia oxidation and found that a large portion of the quinones can be candidates as electron acceptors of ammonia oxidizers (Fig. 5). Theoretically, reduction of quinones in humic acids to hydroquinones can proceed when $E^{0 \prime}$ is above ca. $-0.22 \mathrm{~V}$ at

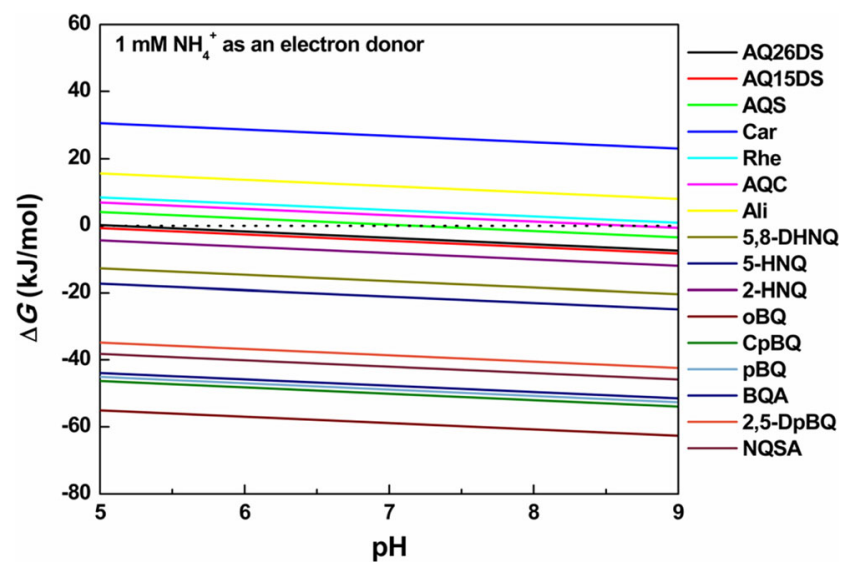

Fig. 5 Gibbs free energy $\Delta G$ (normalized as kJ per mole of $\mathrm{e}^{-}$ transferred) of oxidation of ammonia $(1 \mathrm{mM})$ with diverse quinone species $(1 \mu \mathrm{M})$ commonly used in researches for the studies of humic substances as an electron acceptor alternatively in a $\mathrm{pH}$ range of $5 \sim 9$. The reactions are thermodynamically feasible below the dotted line at $\Delta G=0$ (minimum energy not taken into consideration)

$\mathrm{pH}$ 7.0. At this point, the anaerobic ammonium oxidizing reaction ought to be more widely distributed than supposed previously considering the vast distribution of humic substances in natural environments (Aiken et al. 1985). However, as mentioned above, AQDS is not a surrogate which is equivalent to much more complex humic substances. It remains to be studied whether humic substances can act as electron acceptors of microbial ammonia oxidation.

\subsection{Suramox}

The process of sulfate reduction coupled to anaerobic ammonia oxidation was observed in many bioreactors and named as suramox (Fdz-Polanco et al. 2001; Liu et al. 2008; Zub et al. 2008). The mechanism of the process has been controversial since the reaction was first discovered in an anaerobic fluidized bed reactor in 2001 (Fdz-Polanco et al. 2001). The mostly accepted mechanism can be written as

$\mathrm{NH}_{4}{ }^{+}+1 / 2 \mathrm{SO}_{4}{ }^{2-} \rightarrow 1 / 2 \mathrm{~S}^{0}+1 / 2 \mathrm{~N}_{2}+2 \mathrm{H}_{2} \mathrm{O}$

In suramox reaction, $\mathrm{NH}_{4}{ }^{+}$was presumed to be oxidized to $\mathrm{NO}_{2}{ }^{-}$and then reduced to $\mathrm{N}_{2}$ by anammox bacteria as follows:

$\mathrm{NH}_{4}{ }^{+}+\mathrm{SO}_{4}{ }^{2-} \rightarrow \mathrm{NO}_{2}{ }^{-}+\mathrm{S}^{0}+2 \mathrm{H}_{2} \mathrm{O}$

$\mathrm{NO}_{2}{ }^{-}+\mathrm{NH}_{4}{ }^{+} \rightarrow \mathrm{N}_{2}+2 \mathrm{H}_{2} \mathrm{O}$

These two formulas could be integrated as formula 27 . Therefore, the whole suramox reaction observed in previous 
Table 2 Structures and standard reduction potentials $\left(\mathrm{X}^{0}+2 \mathrm{H}^{+}+2 \mathrm{e}^{-} \leftrightharpoons \mathrm{XH}_{2}\right)$ at $\mathrm{pH} 7.0\left(E^{0 \prime}\right)$ of quinone species

\begin{tabular}{|c|c|c|c|c|}
\hline Name & Abbreviation & Formula & Structure & $E^{09}(\mathrm{~V})$ \\
\hline $\begin{array}{l}\text { 9,10-anthraquinone- } \\
\text { 2,6-disulfonic acid }\end{array}$ & $\begin{array}{l}\text { AQ26DS } \\
\text { (AQDS) }\end{array}$ & $\mathrm{C}_{14} \mathrm{H}_{8} \mathrm{O}_{8} \mathrm{~S}_{2}$ & & -0.184 \\
\hline $\begin{array}{l}\text { 9,10-Anthraquinone- } \\
\text { 1,5-disulfonic acid }\end{array}$ & AQ15DS & $\mathrm{C}_{14} \mathrm{H}_{8} \mathrm{O}_{8} \mathrm{~S}_{2}$ & & -0.175 \\
\hline $\begin{array}{l}\text { 9,10-anthraquinone-2- } \\
\text { sulfonic acid }\end{array}$ & AQS & $\mathrm{C}_{14} \mathrm{H}_{8} \mathrm{O}_{5} \mathrm{~S}$ & & -0.225 \\
\hline
\end{tabular}

7-R-D-

glucopyranosyl-9,10-

dihydro-3,5,6,8-

tetrahydroxy-1 -

Car

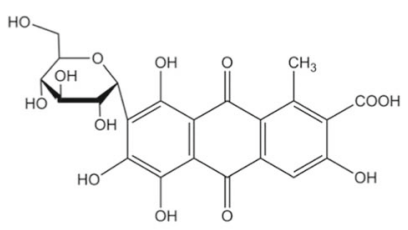

anthracenecarboxylic

9,10-dihydro-4,5-

dihydroxy-9,10-dioxo-

2-anthracene

Rhe

$\mathrm{C}_{15} \mathrm{H}_{8} \mathrm{O}_{6}$

carboxylic acid

(Rhein)<smiles>O=C(O)c1cc(O)c2c(c1)C(=O)c1cccc(O)c1C2=O</smiles>

9,10-anthraquinone-2carboxylic acid

AQC

$\mathrm{C}_{15} \mathrm{H}_{8} \mathrm{O}_{4}$<smiles>O=C(O)c1ccc2c(c1)C(=O)c1ccccc1C2=O</smiles>

$-0.254$

1,2-dihydroxy-9,10anthraquinone

Ali

$\mathrm{C}_{14} \mathrm{H}_{8} \mathrm{O}_{4}$

(Alizarin)<smiles>O=C1c2ccccc2C(=O)c2c1ccc(O)c2O</smiles>

5,8-dihydroxy-1,4naphthoquinone

$\mathrm{C}_{10} \mathrm{H}_{6} \mathrm{O}_{4}$

(Naphthazarin)<smiles>O=C1C=CC(=O)c2c(O)ccc(O)c21</smiles> 
5-hydroxy-1,4naphthoquinone (Juglon)

5-HNQ

$\mathrm{C}_{10} \mathrm{H}_{6} \mathrm{O}_{4}$

2-hydroxy-1,4-

naphthoquinone

2-HNQ

$\mathrm{C}_{10} \mathrm{H}_{6} \mathrm{O}_{3}$

(Lawsone)<smiles>O=C1C=CC(=O)c2c(O)cccc21</smiles>

$-0.003$

o-Benzoquinone

oBQ

$\mathrm{C}_{6} \mathrm{H}_{4} \mathrm{O}_{2}$<smiles>O=C1C=C(O)C(=O)c2ccccc21</smiles><smiles>O=C1C=CC=CC1=O</smiles>

0.389

Chloro-p-

benzoquinone

$\mathrm{CpBQ}$

$\mathrm{C}_{6} \mathrm{H}_{3} \mathrm{O}_{2} \mathrm{Cl}$<smiles>O=C1C=CC(=O)C(Cl)C1</smiles>

$\mathrm{C}_{6} \mathrm{H}_{4} \mathrm{O}_{2}$<smiles>O=C1C=CC(=O)C=C1</smiles>

0.285

p-Benzoquinone

pBQ

Benzoquinonacetic

acid

BQA

$\mathrm{C}_{8} \mathrm{H}_{6} \mathrm{O}_{4}$<smiles>O=C1C=CC(=O)C(CC(=O)O)=C1</smiles>

0.273

2,5-Dimethyl-pbenzoquinone

2,5-DpBQ

$\mathrm{C}_{8} \mathrm{H}_{8} \mathrm{O}_{2}$<smiles>CC1=CC(=O)C(C)=CC1=O</smiles>

0.179

1,2-Naphthoquinone -

NQSA

$\mathrm{C}_{10} \mathrm{H}_{6} \mathrm{O}_{5} \mathrm{~S}$<smiles>O=C1C=C(S(=O)(=O)O)c2ccccc2C1=O</smiles>

0.214

Data of standard reduction potentials at $\mathrm{pH} 7.0\left(E^{0}\right)$ of quinone species were calculated from standard reduction potentials $E^{0}$ or directly from references (Aeschbacher et al. 2011; Rau et al. 2002; Uchimiya and Stone 2006) 


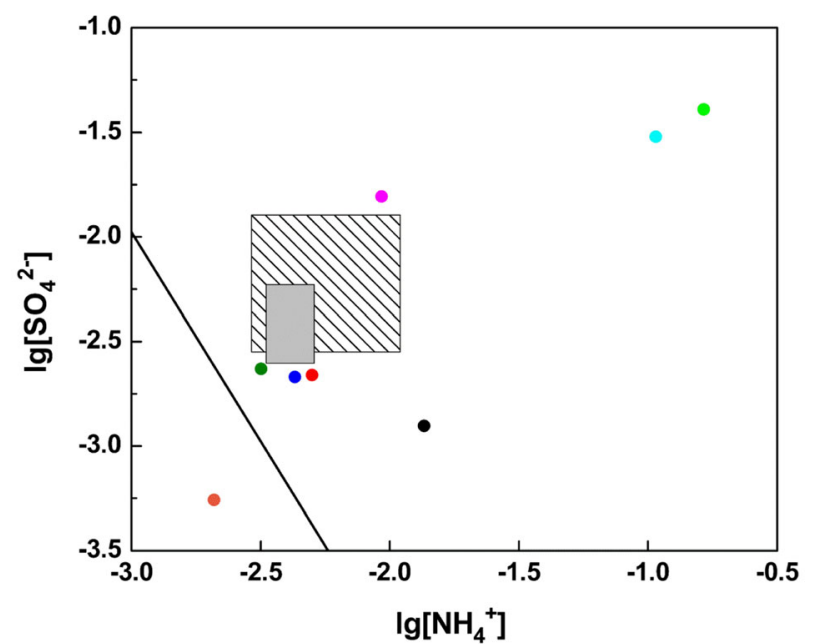

an anaerobic digested sludge bioreactor

NIV an up-flow anaerobic sludge bioreactor

- a granular activated carbon anaerobic fluidised-bed reactor treating vinasse froman ethanol distillery of sugar beet molasses

- an up-flow anaerobic sludge bed reactor with synthetic wastewater

- the sludge taken from the lab-scale reactor treating ammonium and sulfate simultaneously for more than two years

- an upflow anaerobic sludge blanket reactor

- a moving bed biofilm reactor

- a sequencing batch reactor

- an up-flow anaerobic sludge bed reactor

- an up-flow anaerobic sludge bioreactor treating wastewater from baker's yeast production

Fig. 6 The relationship between $\mathrm{SO}_{4}{ }^{2-}$ and $\mathrm{NH}_{4}{ }^{+}$when suramox reaches the thermodynamic equilibrium indicated by the solid line. Above the line, the reaction is thermodynamically feasible (minimum energy not taken into consideration). Shaded areas and dots in different colors reflect data with the occurrence of suramox within reactors taken from previous reports (Fdz-Polanco et al. 2001; Liu et al. 2008; Zub et al. 2008; Yang et al. 2009; Zhang et al. 2009; Cai et al. 2010; Rikmann et al. 2012; Yuan et al. 2013)

studies might be consisted of a series of reactions rather than a simple continual reaction (Liu et al. 2008; Yuan et al. 2013). Schrum et al. (2009) first provided evidence that sulfatereducing ammonium oxidation occurred when upwarddiffusing ammonium contacted the downward-diffusing sulfate in Bay of Bengal sediment. Reported data from these experiments (Fig. 6) indicated that almost all conditions in the experiments were favorable for the suramox reaction. It can be inferred that the suramox reaction can only occur at high substrate concentrations due to its relatively low energy yield, which was corresponded with the result of Zhang et al. (2009).

The existence of anaerobic ammonia oxidation coupled with sulfate reduction has been recognized, but the microorganisms involved have not yet been identified clearly so far. Liu et al. (2008) discovered a new species named Anammoxoglobus sulfate, belonging to Planctomycetales holding a critical role in the first-step reaction (formula 28) of suramox process and showed that the Planctomycete bacteria might have a more versatile metabolism than previously assumed. Cai et al. (2010) isolated a strain named ASR related to Bacillus benzoevorans from an anaerobic ammonia and sulfate removing reactor and identified its ability to

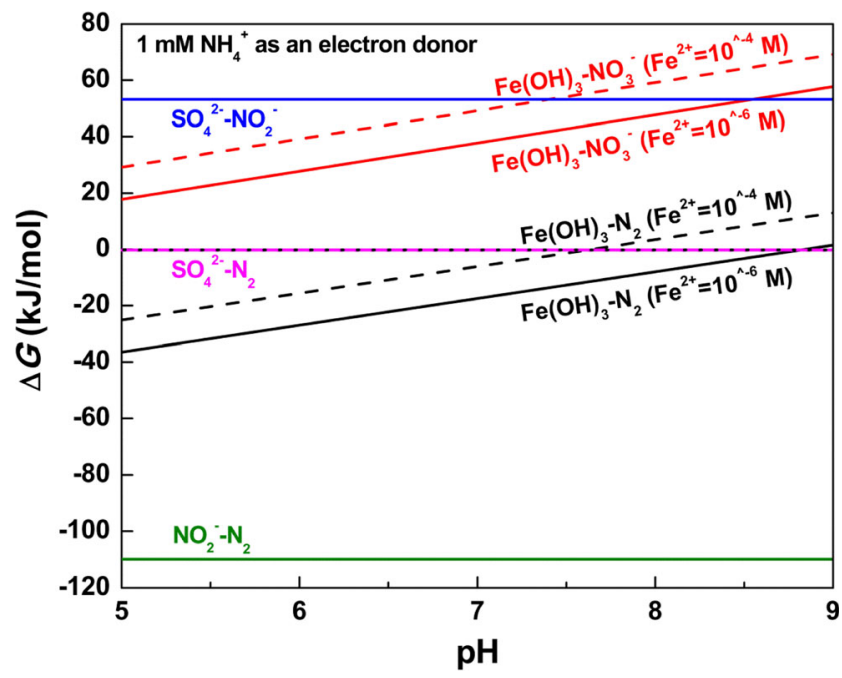

Fig. 7 Gibbs free energy $\Delta G$ of oxidation of ammonia $(1 \mathrm{mM})$ to $\mathrm{N}_{2}$ $\left(10^{-3.47} \mathrm{M}\right)$ or $\mathrm{NO}_{3}{ }^{-} / \mathrm{NO}_{2}{ }^{-}(1 \mathrm{mM})$ with reduction of $\mathrm{NO}_{2}^{-}(1 \mathrm{mM})$ (anammox), $\mathrm{Fe}(\mathrm{OH})_{3}, \mathrm{Fe}^{3+}(1 \mathrm{mM})$ to $\mathrm{Fe}^{2+}\left(10^{-6} \sim 10^{-4} \mathrm{M}\right)$ (feammox), and $\mathrm{SO}_{4}{ }^{2-}(10 \mathrm{mM})$ to $\mathrm{S}^{0}$ (suramox) alternatively in a $\mathrm{pH}$ range of 5 9 (corresponding to formulas 21,23,25, and 27, values of $\Delta G$ are normalized as $\mathrm{kJ}$ per mole of $\mathrm{e}^{-}$transferred). The reactions are thermodynamically feasible below the dotted line at $\Delta G=0$ (minimum energy not taken into consideration)

perform the whole suramox reaction, further widening the knowledge about the structure of potential functional microbial communities implicated in the suramox process. Similarly, in the study of Liu et al. (2015), the dominant bacteria changed from Candidatus brocadia to Bacillus benzoevorans when the process transformed from nitritereducing anaerobic ammonium oxidation to sulfate-reducing anaerobic ammonium oxidation in the sludge reactor.

The discovery of suramox has brought forward a novel high-efficient and low-cost route for the biological removal of ammonium and sulfate in the application of wastewater treatment, compared with traditional separately removing ammonia and sulfate (Zhang et al. 2009). Suramox is usually less thermodynamically feasible than anammox according to our thermodynamic calculation (Fig. 7). Suramox can only happen at high concentrations of $\mathrm{SO}_{4}{ }^{2-}$ and $\mathrm{NH}_{4}{ }^{+}$(Fig. 6), which explains why suramox process was usually only observed in anthropogenic waste water. Though suramox has only been found in few natural environments, this novel reaction widens our knowledge about the biogeochemical cycle between the element nitrogen and sulfur.

\section{Conclusions}

Anaerobic microorganisms mediate a variety of redox reactions, on the one hand gaining energy for their growth and on the other hand driving the biogeochemical cycling of elements in earth's environment. The couplings of 
elements driven by anaerobes are extremely complex since different chemical compounds of different species and activities are linked together. Although we summarize the anaerobe-driven coupling of each pair of elements of $\mathrm{C}-\mathrm{N}, \mathrm{C}-\mathrm{Fe}, \mathrm{C}-\mathrm{S}, \mathrm{N}-\mathrm{Fe}, \mathrm{N}-\mathrm{S}$, and $\mathrm{Fe}-\mathrm{S}$ in this review, the actual situation will be much more intricate because all elements can be microbially associated together, forming a global huge cycle of multiple elements.

Advanced technical tools and methods have been revealing novel microbial reactions truly present on the earth at an amazing rate. However, the mechanism of the reactions and the metabolism and physiology of the associate microbes are far from understanding. Many reactions have been predicted to exist from a thermodynamic perspective but have not yet been identified in natural environments or laboratories. Kinetic constraints of redox reactions need to be taken into consideration for the reason that certain reactions which are possible based on thermodynamic prediction may occur very slowly if the activation energy is high and efficient enzymes are lacking. Further work is required to focus on the metabolic pathways genetically and enzymatically and the factors controlling the feasibility of the reactions. Moreover, the dynamic balance between the various redox processes needs to be explored for a better understanding how microbes transition metabolic strategies to adapt to changing geochemical conditions. Especially, more work has to be carried out on organic carbon such as the molecular composition, structure, and properties of organic carbon and how organic carbon is involved in microbial activities because carbon is the most abundant element in organisms and the geochemical cycle of carbon is extremely important to all living organisms on the earth.

Acknowledgements This work was financially supported by the State Key Program of Natural Science Foundation of China (No. 41430858), the National Natural Science Foundation of China (No. 41571130062), and National Key Research and Development Program of China (2016YFD0800400).

\section{Compliance with ethical standards}

Conflict of interest The authors declare no competing financial interest.

\section{References}

Aeschbacher M, Vergari D, Schwarzenbach RP, Sander M (2011) Electrochemical analysis of proton and electron transfer equilibria of the reducible moieties in humic acids. Environ Sci Technol 45: 8385-8394

Aiken GR, Mcknight DM, Wershaw RL, Maccarthy P (1985) Humic substances in soil, sediment, and water: geochemistry, isolation, and characterization. John Wiley \& Sons, New York

Amend JP, Shock EL (2001) Energetics of overall metabolic reactions of thermophilic and hyperthermophilic archaea and bacteria. FEMS Microbiol Rev 25:175-243
Aranda-Tamaura C, Estrada-Alvarado MI, Texier AC, Cuervo F, Gómez J, Cervantes FJ (2007) Effects of different quinoid redox mediators on the removal of sulphide and nitrate via denitrification. Chemosphere 69:1722-1727

Balci S, Dincel Y (2002) Ammonium ion absorption with sepolite: use of transient uptake method. Chem Eng Process 41:70-85

Beal EJ, House CH, Orphan VJ (2009) Manganese- and iron-dependent marine methane oxidation. Science 325:184-187

Bender M, Jahnke R, Ray W, Martin W, Heggie DT, Orchardo J, Sowers $\mathrm{T}$ (1989) Organic carbon oxidation and benthic nitrogen and silica dynamics in San Clemente Basin, a continental borderland site. Geochim Cosmochim Acta 53:685-697

Benz M, Brune A, Schink B (1998) Anaerobic and aerobic oxidation of ferrous iron at neutral $\mathrm{pH}$ by chemoheterotrophic nitrate-reducing bacteria. Arch Microbiol 169:159-165

Bethke CM, Sanford RA, Kirk MF, Jin Q, Flynn TM (2011) The thermodynamic ladder in geomicrobiology. Am J Sci 311:183-210

Blankenship RE, Madigan MT, Bauer CE (eds) (1995) Anoxygenic photosynthetic bacteria. Kluwer, Dordrecht

Blöthe M, Roden EE (2009) Composition and activity of an autotrophic $\mathrm{Fe}(\mathrm{II})$-oxidizing, nitrate-reducing enrichment culture. Appl Environ Microbiol 75:6937-6940

Boesen C, Postma D (1988) Pyrite formation in anoxic environments of the Baltic. Amer J Sci 288:575-603

Bond DR, Lovley DR (2002) Reduction of Fe(III) oxide by methanogens in the presence and absence of extracellular quinones. Environ Microbiol 4:115-124

Burgin AJ, Hamilton SK (2008) $\mathrm{NO}_{3}{ }^{-}$-driven $\mathrm{SO}_{4}{ }^{2-}$ production in freshwater ecosystems: implications for $\mathrm{N}$ and $\mathrm{S}$ cycling. Ecosystems 11: 908-922

Burgin AJ, Yang WH, Hamilton SK, Silver WL (2011) Beyond carbon and nitrogen: how the microbial energy economy couples elemental cycles in diverse ecosystems. Front Ecol Environ 9:44-52

Cai J, Jiang JX, Zheng P (2010) Isolation and identification of bacteria responsible for simultaneous anaerobic ammonium and sulfate removal. Sci China Chem 53:645-665

Canfield DE, Raiswell R (1999) The evolution of the sulfur cycle. Am J Sci 299:697-723

Canfield DE, Jørgensen BB, Fossing H, Glud R, Gundersen J, Ramsing NB, Thamdrup B, Hansen JW, Nielsen LP, Hall PO (1993) Pathways of organic carbon oxidation in three continental margin sediments. Mar Geol 113:7-40

Canfield DE, Rosing MT, Bjerrum C (2006) Early anaerobic metabolisms. Philos Trans R Soc Lond Ser B Biol Sci 361:1819-1834

Chakraborty A, Roden EE, Schieber J, Picardal F (2011) Enhanced growth of Acidovorax sp. strain $2 \mathrm{AN}$ during nitrate-dependent $\mathrm{Fe}(\mathrm{II})$ oxidation in batch and continuous-flow systems. Appl Environ Microbiol 77:8548-8556

Chaudhuri SK, Lack JG, Coates JD (2001) Biogenic magnetite formation through anaerobic biooxidation of Fe(II). Appl Environ Microbiol 67:2844-2848

Clément JC, Shrestha J, Ehrenfeld JG, Jaffé PR (2005) Ammonium oxidation coupled to dissimilatory reduction of iron under anaerobic conditions in wetland soils. Soil Biol Biochem 37:2323-2328

Conrad R, Schink B, Phelps TJ (1986) Thermodynamics of $\mathrm{H}_{2}$-consuming and $\mathrm{H}_{2}$-producing metabolic reactions in diverse methanogenic environments under in situ conditions. FEMS Microbiol Ecol 38: 353-360

Crowe SA, Jones C, Katsev S, Magen C, O'Neill AH, Sturm A, Canfield DE, Haffner GD, Mucci A, Sundby B, Fowle DA (2008) Photoferrotrophs thrive in an Archean Ocean analogue. Proc Natl Acad Sci U S A 105:15938-15943

Dale OR, Tobias CR, Bongkeun S (2009) Biogeographical distribution of diverse anaerobic ammonium oxidizing (anammox) bacteria in Cape Fear River Estuary. Environ Microbiol 11:1194-1207 
Dalsgaard T, Canfield DE, Petersen J, Thamdrup B, Acuna-Gonzalez J (2003) $\mathrm{N}_{2}$ production by the anammox reaction in the anoxic water column of Golfo Dulce, Costa Rica. Nature 422:606-608

Dalsgaard T, Thamdrup B (2002) Factors controlling anaerobic ammonium oxidation with nitrite in marine sediments. Appl Environ Microbiol 68:3802-3808

Ding LJ, An XL, Li S, Zhang GL, Zhu YG (2014) Nitrogen loss through anaerobic ammonium oxidation coupled to iron reduction from paddy soils in a chronosequence. Environ Sci Technol 48:10641-10647

Ehrenreich A, Widdel F (1994) Anaerobic oxidation of ferrous iron by purple bacteria, a new type of phototrophic metabolism. Appl Environ Microbiol 60:4517-4526

Engstrom P, Penton CR, Devola AH (2009) Anaerobic ammonium oxidation in deep-sea sediments off the Washington margin. Limnol Oceanogr 54:1643-1652

Ettwig KF, Butler MK, Le Paslier D, Pelletier E, Mangenot S, Kuypers MM, Schreiber F, Dutilh BE, Zedelius J, de Beer D, Gloerich J, Wessels HJ, van Alen T, Luesken F, Wu ML, van de PasSchoonen KT, Op den Camp HJ, Janssen-Megens EM, Francoijs KJ, Stunnenberg H, Weissenbach J, Jetten MS, Strous M (2010) Nitrite-driven anaerobic methane oxidation by oxygenic bacteria. Nature 464:543-548

Fdz-Polanco F, Fdz-Polanco M, Fernandez N, Uruena MA, Garcia PA, Villaverde S (2001) New process for simultaneous removal of nitrogen and sulfur under anaerobic conditions. Water Res 35:1111-1114

Flynn TM, O'Loughlin EJ, Mishra B, DiChristina TJ, Kemner KM (2014) Sulfur-mediated electron shuttling during bacterial iron reduction. Science 344:1039-1042

Fossing H, Gallardo VA, Jørgensen BB, Huttel M, Nielsen LP, Schlz H, Canfield DE, Forster S, Glud RN, Gyndersen JK, Kuver J, Ramsing NB, Teske A, Thamdrup B, Ulloa O (1995) Concentration and transport of nitrate by the mat-forming sulphur bacterium Thioploca. Nature 374:713-715

Froelich PN, Klinkhammer GP, Bender ML, Luedtke NA, Heath GR, Cullen D, Dauphin P, Hammond D, Hartman B, Maynard V (1979) Early oxidation of organic-matter in pelagic sediments of the eastern equatorial Atlantic: suboxic diagenesis. Geochim Cosmochim Acta 43:1075-1090

Hamersley MR, Woebken D, Boehrer B, Schultze M, Lavik G, Kuypers MM (2009) Water column anammox and denitrification in a temperate permanently stratified lake (Lake Rassnitzer, Germany). System Appl Microbiol 32:571-582

Hansen HCB, Koch CB, Nancke-Krogh H, Borggaard OK, Sørensen J (1996) Abiotic nitrate reduction to ammonium: key role of green rust. Environ Sci Technol 30:2053-2056

Haroon MF, Hu S, Shi Y, Imelfort M, Keller J, Hugenholtz P, Yuan ZG, Tyson GW (2013) Anaerobic oxidation of methane coupled to nitrate reduction in a novel archaeal lineage. Nature 500:567-570

Hoehler TM, Alperin MJ, Albert DB, Martens CS (1994) Field and laboratory studies of methane oxidation in an anoxic marine sediment: evidence for a methanogen-sulfate reducer consortium. Glob Biogeochem Cycles 8:451-463

Huang DY, Zhuang L, Cao WD, Xu W, Zhou SG, Li FB (2010) Comparison of dissolved organic matter from sewage sludge and sludge compost as electron shuttles for enhancing Fe(III) bioreduction. J Soils Sediments 10:722-729

Huang XL, Gao DW, Peng S, Tao Y (2014) Effects of ferrous and manganese ions on anammox process in sequencing batch biofilm reactors. J Environ Sci 26:1034-1039

Jackson BE, McInerney MJ (2002) Anaerobic microbial metabolism can proceed close to thermodynamic limits. Nature 415:454-456

Jaeschke A, den Camp HJO, Harhangi H, Klimiuk A, Hopmans EC, Jetten MS, Schouten S, Sinninghe Damste JS (2009a) 16S rRNA gene and lipid biomarker evidence for anaerobic ammoniumoxidizing bacteria (anammox) in California and Nevada hot springs. FEMS Microbiol Ecol 67:343-350
Jaeschke A, Hopmans EC, Wakeham SG, Schouten S, Damste JS (2007) The presence of ladderane lipids in the oxygen minimum zone of the Arabian Sea indicates nitrogen loss through anammox. Limnol Oceanogr 52:780-786

Jaeschke A, Rooks C, Trimmer M, Nicholls JC, Hopmans EC, Schouten S, Damsté JSS (2009b) Comparison of ladderane phospholipid and core lipids as indicators for anaerobic ammonium oxidation (anammox) in marine sediments. Geochim Cosmochim Acta 73: 2077-2088

Jin Q, Bethke CM (2003) A new rate law describing microbial respiration. Appl Environ Microbiol 69:2340-2348

Jin Q, Bethke CM (2007) The thermodynamics and kinetics of microbial metabolism. Amer J Sci 307:643-677

Jin Q, Bethke CM (2009) Cellular energy conservation and the rate of microbial sulfate reduction. Geology 37:1027-1030

Kappler A, Newman DK (2004) Formation of Fe(III)-minerals by Fe(II)oxidizing photoautotrophic bacteria. Geochim Cosmochim Acta 68: $1217-1226$

Kasting JF (1993) Earth's early atmosphere. Science 259:920-926

Klüpfel L, Piepenbrock A, Kappler A, Sander M (2014) Humic substances as fully regenerable electron acceptors in recurrently anoxic environments. Nat Geosci 7:195-200

Kuypers MMM, Sliekers AO, Lavik G, Schmid M, Jørgensen BB, Kuenen JG, Sinninghe Damste JS, Strous M, Jetten MSM (2003) Anaerobic ammonium oxidation by anammox bacteria in the Black Sea. Nature 422:608-611

Laufer K, Røy H, Jørgensen BB, Kappler A (2016) Evidence for the existence of autotrophic nitrate-reducing $\mathrm{Fe}(\mathrm{II})$-oxidizing bacteria in marine coastal sediment. Appl Eviron Microbiol 82:6120-6131

Lide DR (2012) CRC handboook of chemistry and physics. CRC Press, Boca Raton

Liu ST, Yang FL, Gong Z, Meng FG, Chen HH, Xue Y, Furukawa K (2008) Application of anaerobic ammonium oxidizing consortium to achieve completely autotrophic ammonium and sulfate removal. Bioresour Technol 99:6817-6825

Liu ZC, Yuan LJ, Zhou GB, Li J (2015) Achievement of sulfate-reducing anaerobic ammonium oxidation reactor started with nitrate-reducing anaerobic ammonium oxidation. Envirn Sci 36:3345-3351

Li XF, Hou LJ, Liu M, Zheng YL, Yin GY, Lin XB, Cheng L, Li Y, Hu XT (2015) Evidence of nitrogen loss from anaerobic ammonium oxidation coupled with ferric iron reduction in an intertidal wetland. Environ Sci Technol 49:11560-11568

Majzlan J, Lang BE, Stevens R, Navrotsky A, Woodfield BF, BoerioGoates J (2003) Thermodynamics of Fe oxides: part I. Entropy at standard temperature and pressure and heat capacity of goethite $(\alpha-$ $\mathrm{FeOOH})$, lepidocrocite $(\gamma$-FeOOH$)$, and maghemite $\left(\gamma-\mathrm{Fe}_{2} \mathrm{O}_{3}\right)$. Am Mineral 88:846-854

Majzlan J, Navrotsky A, Schwertmann U (2004) Thermodynamics of iron oxides: part III. Enthalpies of formation and stability of ferrihydrite $\left(\sim \mathrm{Fe}(\mathrm{OH})_{3}\right)$, schwertmannite $\left(\sim \mathrm{FeO}(\mathrm{OH})_{3 / 4}\left(\mathrm{SO}_{4}\right)_{1 / 8}\right)$, and $\varepsilon$ $\mathrm{Fe}_{2} \mathrm{O}_{3}$. Geochim Cosmochim Acta 68:1049-1059

Martin JH (1990) Glacial-interglacial $\mathrm{CO}_{2}$ change: the iron hypothesis. Paleoceanography 5:1-13

McGlynn SE, Chadwick GL, Kempes CP, Orphan VJ (2015) Single cell activity reveals direct electron transfer in methanotrophic consortia. Nature 526:531-535

Milucka J, Ferdelman TG, Polerecky L, Franzke D, Wegener G, Schmid M, Lieberwirth I, Wagner M, Widdel F, Kuypers MMM (2012) Zero-valent sulphur is a key intermediate in marine methane oxidation. Nature 491:541-546

Miot J, Benzerara K, Obst M, Kappler A, Hegler F, Schädler S, Bouchez C, Guyot F, Morin G (2009) Extracellular iron biomineralization by photoautotrophic iron-oxidizing bacteria. Appl Environ Microbiol 75:5586-5591 
Moran JJ, Beal EJ, Vrentas JM, Orphan VJ, Freeman KH, House CH (2008) Methyl sulfides as intermediates in the anaerobic oxidation of methane. Environ Microbiol 10:162-173

Muehe EM, Gerhardt S, Schink B, Kappler A (2009) Ecophysiology and the energetic benefit of mixotrophic $\mathrm{Fe}(\mathrm{II})$ oxidation by various strains of nitrate-reducing bacteria. FEMS Microbiol Ecol 70:335343

Neal AL, Techkarnjanaruk S, Dohnalkova A, McCready D, Peyton BM, Geesey GG (2001) Iron sulfides and sulfur species produced at hematite surfaces in the presence of sulfate-reducing bacteria. Geochim Cosmochim Acta 65:223-235

Newman DK, Kolter R (2000) A role for excreted quinones in extracellular electron transfer. Nature 405:94-97

Ottley CJ, Davison W, Edmunds WM (1997) Chemical catalysis of nitrate reduction by iron(II). Geochim Cosmochim Acta 61:18191828

Park W, Nam YK, Lee MJ, Kim TH (2009) Anaerobic ammoniaoxidation coupled with $\mathrm{Fe}^{3+}$ reduction by an anaerobic culture from a piggery wastewater acclimated to $\mathrm{NH}_{4}^{+} / \mathrm{Fe}^{3+}$ medium. Biotechnol Bioprocess Eng 14:680-685

Patrick WH, Jugsujinda A (1992) Sequential reduction and oxidation of inorganic nitrogen, manganese, and iron in flooded soil. Soil Sci Soc Amer J 56:1071-1073

Payne EK, Burgin AJ, Hamilton SK (2009) Sediment nitrate manipulation using porewater equilibrators reveals potential for $\mathrm{N}$ and $\mathrm{S}$ coupling in freshwaters. Aquat Microb Ecol 4:233-241

Peng XT, Guo ZX, Chen S, Sun ZL, Xu HC, Ta KW, Zhang JC, Zhang LJ, Li JW, Du MG (2017) Formation of carbonate pipes in the northern Okinawa Trough linked to strong sulfate exhaustion and iron supply. Geochim Cosmochim Acta 205:1-13

Picardal F (2012) Abiotic and microbial interactions during anaerobic transformations of $\mathrm{Fe}(\mathrm{II})$ and $\mathrm{NO}_{\mathrm{x}}$. Front Microbiol 3:1-7

Postma D, Jakobsen R (1996) Redox zonation: equilibrium constraints on the $\mathrm{Fe}(\mathrm{III}) / \mathrm{SO}_{4}{ }^{-}$reduction interface. Geochim Cosmochim Acta 60: 3169-3175

Raghoebarsing AA, Pol A, van de Pas-Schoonen KT, Smolders AJ, Ettwig KF, Rijpstra WI, Schouten S, Damste JS, Op den Camp HJ, Jetten MS, Strous M (2006) A microbial consortium couples anaerobic methane oxidation to denitrification. Nature 440:918-921

Rau J, Knackmuss HJ, Stolz A (2002) Effects of different quinoid redox mediators on the anaerobic reduction of azo dyes by bacteria. Environ Sci Technol 36:1497-1504

Reeburgh WS (2007) Oceanic methane biogeochemistry. Chem Rev 107: 486-513

Rich JJ, Dale OR, Song B, Ward BB (2008) Anaerobic ammonium oxidation (anammox) in Chesapeake Bay sediments. Microb Ecol 55: 311-320

Rikmann E, Zekker I, Tomingas M, Tenno T, Menert A, Loorits L, Tenno $\mathrm{T}$ (2012) Sulfate-reducing anaerobic ammonium oxidation as a potential treatment method for high nitrogen-content wastewater. Biodegradation 23:509-524

Robertson EK, Roberts KL, Burdorf LD, Cook P, Thamdrup B (2016) Dissimilatory nitrate reduction to ammonium coupled to $\mathrm{Fe}(\mathrm{II})$ oxidation in sediments of a periodically hypoxic estuary. Limnol Oceanogr 61:365-381

Roden EE, Kappler A, Bauer I, Jie J, Paul A, Stoesser R, Konishi H, Xu HF (2010) Extracellular electron transfer through microbial reduction of solid-phase humic substances. Nat Geosci 3:417-421

Rysgaard S, Glud RN (2004) Anaerobic $\mathrm{N}_{2}$ production in Arctic sea ice. Limnol Oceanogr 49:86-94

Sawayama S (2006) Possibility of anoxic ferric ammonium oxidation. J Biosci Bioeng 101:70-72

Scheller S, Yu H, Chadwick GL, McGlynn SE, Orphan VJ (2016) Artificial electron acceptors decouple archaeal methane oxidation from sulfate reduction. Science 351:703-707
Schmid MC, Risgaard-Petersen N, van de Vossenberg J, Kuypers MM, Lavik G, Petersen J, Hulth S, Thamdrup B, Canfield D, Dalsgaard T, Rysgaard S, Sejr MK, Strous M, den Camp HJ, Jetten MS (2007) Anaerobic ammonium-oxidizing bacteria in marine environments: widespread occurrence but low diversity. Environ Microbiol 9: 1476-1484

Schrum HN, Spivack AJ, Kastner M, D’Hondt S (2009) Sulfate reducing ammonium oxidation: a thermodynamically feasible metabolic pathway in subseafloor sediment. Geology 37:939-942

Schubert CJ, Durisch-Kaiser E, Wehrli B, Thamdrup B, Lam P, Kuypers MMM (2006) Anaerobic ammonium oxidation in a tropical freshwater system (Lake Tanganyika). Environ Microbiol 8:1857-1863

Scott DT, McKnight DM, Blunt-Harris EL, Kolesar SE, Lovley DR (1998) Quinone moieties act as electron acceptors in the reduction of humic substances by humics-reducing microorganisms. Environ Sci Technol 32:2984-2989

Shen JP, Xu Z, He JZ (2014) Frontiers in the microbial processes of ammonia oxidation in soils and sediments. J Soils Sediments 14: 1023-1029

Shrestha J, Rich JJ, Ehrenfeld JG, Jaffe PR (2009) Oxidation of ammonium to nitrite under iron-reducing conditions in wetland soils: laboratory, field demonstrations, and push-pull rate determination. Soil Sci 174:156-164

Sørensen J, Thorling L (1991) Stimulation by lepidocrocite of Fe(II)dependent nitrite reduction. Geochim Cosmochim Acta 55:12891294

Straub KL, Benz M, Schink B, Widdel F (1996) Anaerobic, nitratedependent microbial oxidation of ferrous iron. Appl Environ Microbiol 62:1458-1460

Straub KL, Schönhuber WA, Buchholz-Cleven BE, Schink B (2004) Diversity of ferrous iron-oxidizing, nitrate-reducing bacteria and their involvement in oxygen-independent iron cycling. Geomicrobiol J 21:371-378

Tice MM, Lowe DR (2004) Photosynthetic microbial mats in the 3,416Myr-old ocean. Nature 431:549-552

Uchimiya M, Stone AT (2006) Redox reactions between iron and quinones: thermodynamic constraints. Geochim Cosmochim Acta 70: 1388-1401

Wang XN, Sun GX, Li XM, Clarke TA, Zhu YG (2017) Electron shuttlemediated microbial $\mathrm{Fe}(\mathrm{III})$ reduction under alkaline conditions. J Soils Sediments. doi:10.1007/s11368-017-1736-y

Wegener G, Krukenberg V, Riedel D, Tegetmeyer HE, Boetius A (2015) Intercellular wiring enables electron transfer between methanotrophic archaea and bacteria. Nature 526:587-590

Widdel F, Schnell S, Heising S, Ehrenreich A, Assmus B, Schink B (1993) Ferrous iron oxidation by anoxygenic phototrophic bacteria. Nature 362:834-836

Yang X, Huang S, Wu Q, Zhang R (2012a) Nitrate reduction coupled with microbial oxidation of sulfide in river sediment. J Soils and Sediments 12:1435-1444

Yang WH, Weber KA, Silver WL (2012b) Nitrogen loss from soil through anaerobic ammonium oxidation coupled to iron reduction. Nat Geosci 5:538-541

Yang Z, Zhou S, Sun Y (2009) Start-up of simultaneous removal of ammonium and sulfate from an anaerobic ammonium oxidation (anammox) process in an anaerobic up-flow bioreactor. J Hazard Mater 169:113-118

Yuan Y, Huang Y, Li X, Zhang CL, Zhang L, Pan Y, Liu FX (2013) Characteristics of sulfate reduction-ammonia oxidation reaction. Environ Sci 34:4362-4369

Zehnder AJ, Brock TD (1980) Anaerobic methane oxidation: occurrence and ecology. Appl Environ Microbiol 39:194-204

Zhang L, Zheng P, He YH, Jin RC (2009) Performance of sulfatedependent anaerobic ammonium oxidation. Sci China Ser B: Chem 52:86-92 
Zhou GW, Yang XR, Li H, Marshall CW, Zheng BX, Yan Y, Su JQ, Zhu YG (2016) Electron shuttles enhance anaerobic ammonium oxidation coupled to iron(III) reduction. Environ Sci Technol 50:92989307

Zhu GB, Peng YZ, Li BK, Guo JH, Yang Q, Wang SY (2008) Biological removal of nitrogen from wastewater. Rev Environ Contam T 192: $159-195$

Zhu GB, Wang SY, Zhou LL, Wang Y, Zhao SY, Xia C, Wang WD, Zhou R, Wang CX, Jetten MS, Hefting MM, Yin CQ, Qu JH (2015)
Ubiquitous anaerobic ammonium oxidation in inland waters of China: an overlooked nitrous oxide mitigation process. Sci Rep 5: $1-10$

Zhu YG, Duan GL, Chen BD, Peng XH, Chen Z, GX S (2014) Mineral weathering and element cycling in soil-microorganism-plant system. Sci China Earth Sci 57:888-896

Zub S, Kurissoo T, Menert A, Blonskaja V (2008) Combined biological treatment of high-sulphate wastewater from yeast production. Water Environ J 22:274-286 